\title{
Prenatal transportation stress alters genome-wide DNA methylation in suckling Brahman bull calves ${ }^{1,2}$
}

\author{
Brittni P. Littlejohn, ${ }^{*, \dagger}$ Deborah M. Price, ${ }^{*, \dagger}$ Don A. Neuendorff,* Jeffery A. Carroll, ${ }^{\dagger}$ Rhonda C. Vann, \\ Penny K. Riggs, ${ }^{\dagger}$ David G. Riley, ${ }^{\dagger}$ Charles R. Long, ${ }^{*, \dagger}$ Thomas H. Welsh, Jr., ${ }^{\dagger}$ and Ronald D. Randel*,3
}

*Texas A\&M AgriLife Research \& Extension Center, Overton, TX 75684; ${ }^{`}$ Department of Animal Science, Texas A\&M University, and Texas A\&M AgriLife Research, College Station, TX 77843; ‘USDA-ARS, Livestock Issues Research Unit, Lubbock, TX 79403; and "Mississippi Agricultural and Forestry Experiment Station, Mississippi State University, Raymond, MS 39154

\begin{abstract}
The objective of this experiment was to identify genome-wide differential methylation of DNA in young prenatally stressed (PNS) bull calves. Mature Brahman cows $(n=48)$ were transported for $2-\mathrm{h}$ periods at $60 \pm 5,80 \pm 5$, $100 \pm 5,120 \pm 5$, and $140 \pm 5 \mathrm{~d}$ of gestation or maintained as nontransported Controls $(n=48)$. Methylation of DNA from white blood cells from a subset of 28-d-old intact male offspring ( $n=7$ PNS; $n=7$ Control) was assessed via reduced representation bisulfite sequencing. Samples from PNS bulls contained 16,128 CG, $226 \mathrm{CHG}$, and $391 \mathrm{CHH}$ $(\mathrm{C}=$ cytosine $\mathrm{G}=$ guanine; $\mathrm{H}=$ either adenine, thymine, or cytosine) sites that were differentially methylated compared to samples from Controls. Of the CG sites, 7,407 were hypermethylated (at least 10\% more methylated than Controls; $P \leq$

0.05 ) and 8,721 were hypomethylated (at least $10 \%$ less methylated than Controls; $P \leq 0.05$ ). Increased DNA methylation in gene promoter regions typically results in decreased transcriptional activity of the region. Therefore, differentially methylated CG sites located within promoter regions $(n=1,205)$ were used to predict (using Ingenuity Pathway Analysis software) alterations to canonical pathways in PNS compared with Control bull calves. In PNS bull calves, 113 pathways were altered $(P$ $\leq 0.05$ ) compared to Controls. Among these were pathways related to behavior, stress response, metabolism, immune function, and cell signaling. Genome-wide differential DNA methylation and predicted alterations to pathways in PNS compared with Control bull calves suggest epigenetic programming of biological systems in utero.
\end{abstract}

Key words: Bos indicus, calves, DNA methylation, epigenetics, prenatal stress, reduced representation bisulfite sequencing

(C) The Author (s) 2018. Published by Oxford University Press on behalf of the American Society of Animal Science. All rights reserved. For permissions, please e-mail: journals.permissions@oup.com.

J. Anim. Sci. 2018.96:5075-5099 doi: $10.1093 /$ jas/sky350

\footnotetext{
${ }^{1}$ This work was supported by Texas A\&M AgriLife Research, Western Regional project TEX03212, Hatch project H-9022, and the TAMU One Health Initiative.

${ }^{2}$ Mention of trade names or commercial products in this article is solely for the purpose of providing specific information and does not imply recommendation or endorsement by the U.S. Department of Agriculture. The U.S. Department of Agriculture (USDA) prohibits discrimination in all its programs and activities on the basis of race, color, national origin, age, disability, and where applicable, sex, marital status, familial status, parental status, religion, sexual orientation, genetic information, political beliefs, reprisal, or because all or part of an individual's income is derived from any public
}

assistance program. (Not all prohibited bases apply to all programs.) Persons with disabilities who require alternative means for communication of program information (Braille, large print, audiotape, etc.) should contact USDA's TARGET Center at (202) 720-2600 (voice and TDD). To file a complaint of discrimination, write to USDA, Director, Office of Civil Rights, 1400 Independence Avenue, S.W., Washington, DC. 20250-9410, or call (800) 795-3272 (voice) or (202) 720 6382 (TDD). USDA is an equal opportunity provider and employer.

${ }^{3}$ Corresponding author: r-randel@tamu.edu

Received May 21, 2018.

Accepted August 27, 2018. 


\section{INTRODUCTION}

Environmental stimuli or stressors incurred by a gestating dam can alter postnatal phenotypes of the offspring (Clarke et al., 1996; Lay et al., 1997; Mueller and Bale, 2008). In response to a stressor experienced by a gestating female, the placental barrier enzyme 11- $\beta$ HSD2 might be suppressed. Because 11- $\beta$ HSD2 functions to convert cortisol to an inactive form before crossing the placenta to fetal circulation, decreased $11-\beta H S D 2$ results in increased exposure of the fetus to corticosteroids (Benediktsson et al., 1997; Stirrat et al., 2018). Altered prenatal environment affects postnatal outcomes, in part, by epigenetic modifications, such as DNA methylation (Szyf, 2012). DNA methylation is a covalent modification in which a methyl group is added to the carbon 5 position of a cytosine nucleotide (Wyatt, 1950; Razin and Riggs et al., 1980). This chemical modification of DNA plays a crucial role in regulating unique functions between different cell types, despite each cell type having an identical genome (Razin and Riggs, 1980; Suelves et al., 2016). It is not well understood how a prenatal or life experience might alter DNA methylation differently between cell types, though there is evidence that immune cells and brain cells can be similarly influenced (Provençal et al., 2012; Massart et al., 2016a). Increased methylation of DNA in promoter regions of a gene has been reported to suppress transcription and gene expression (Levine et al., 1991; Tate and Bird, 1993). Alternatively, increased methylation of DNA in gene body regions (i.e., introns and exons) may increase gene expression (Hellman and Chess, 2007). Therefore, characterization of methylation status of DNA in promoter and gene body regions may provide insight regarding the influence of prenatal environment on postnatal phenotype. Beef cattle health, animal welfare/well-being, behavior, and production trait phenotypes are important to producers and consumers. This study investigated how environmental stressors incurred by gestating dams could affect relevant traits in beef cattle, by evaluating the influence of prenatal transportation stress on genome-wide DNA methylation in their offspring. We hypothesized that prenatal transportation stress would alter genome-wide methylation of DNA from white blood cells (WBC) of 28-d-old Brahman bull calves.

\section{MATERIALS AND METHODS}

All experimental procedures were in compliance with the Guide for the Care and Use of Agricultural Animals in Research and Teaching (FASS, 2010) and were approved by the Texas A\&M University Animal Care and Use Committee.

\section{Animal Procedures}

Multiparous Brahman cows were assigned to 1 of 2 treatment groups (Transported: $n=48$ and Control: $n=48$ ) according to age, parity, and temperament (Littlejohn et al., 2016). Transported cows were hauled for a 2-h duration at $60 \pm 5,80 \pm 5$, $100 \pm 5,120 \pm 5$, and $140 \pm 5 \mathrm{~d}$ of gestation (Price et al., 2015). Control cows were maintained in the same manner as Transported cows with the exception of being transported. The 2 groups were housed in the same pasture (at the Texas A\&M AgriLife Research and Extension Center at Overton, TX) and fed the same diet (Littlejohn et al., 2016). From these cows, 26 male and 18 female calves (Control group) were born to Control dams, while 20 male and 21 female calves [prenatally stressed (PNS) group] were born to Transported dams. Male calves were maintained as bulls throughout the study. Each calf was restrained manually at $28 \mathrm{~d}$ of age for less than $5 \mathrm{~min}$ for blood sample collection. One 10-mL vacuum tube (BD, Franklin Lakes, NJ) containing EDTA was used for blood sample collection from each calf via jugular venipuncture with a sterile 18-gauge needle. The WBC were isolated and stored at $-80^{\circ} \mathrm{C}$ until DNA was extracted. For methylation analysis, samples from bull calves were stratified into groups based on the following criteria: 1) adequate availability of DNA, 2) calf treatment group, and 3) calf sire. From those stratified groups, samples from 7 PNS and 7 Control bull calves were randomly selected for this study. Our lab chose to focus on bull calves rather than heifer calves because of the reported transgenerational impact of PNS attributed to the male germline (Rodgers et al., 2013; Rodgers and Bale, 2015).

\section{Sample Analysis}

Processing of blood samples. Blood samples were centrifuged at $2,671 \times g$ for $30 \mathrm{~min}$ at $6{ }^{\circ} \mathrm{C}$. The WBC layer was isolated and transferred into $2-\mathrm{mL}$ nuclease-free microcentrifuge tubes. Samples were repeatedly washed in red blood cell lysis buffer solution until a clean cell pellet was produced. Specifically, one wash included the following: red blood cell lysis buffer was added to the tube, mixed by vortex for $20 \mathrm{~s}$, shaken for $3 \mathrm{~min}$, centrifuged at $1600 \times g$ for $5 \mathrm{~min}$, and the supernatant was discarded. Clean WBC pellets were stored at $-80{ }^{\circ} \mathrm{C}$ until they were thawed for DNA extraction. 
DNA extraction. Phenol-chloroform extraction procedures were used to isolate DNA from each WBC pellet for methylation analysis. The following description summarizes extraction procedures: Samples were removed from the $-80{ }^{\circ} \mathrm{C}$ freezer and placed on wet ice for thawing and kept on ice between procedural steps. White blood cell pellets were homogenized in extraction buffer $(100 \mathrm{mM}$ $\mathrm{NaCl}, 10 \mathrm{mM}$ Tris, $1 \mathrm{mM}$ EDTA, $\mathrm{pH}$ 7.5), to which $10 \mathrm{mg} / \mathrm{mL}$ proteinase $\mathrm{K}$ and $20 \% \mathrm{SDS}$ was added for proteinase $\mathrm{K}$ digestion and incubated at $55^{\circ} \mathrm{C}$ for $2 \mathrm{~h}$. Samples were extracted twice with an equal volume of phenol:chloroform:isoamyl alcohol (25:24:1) and twice with an equal volume of 1-bromo-3-chloropropane (substituted for chloroform). After each extraction, samples underwent centrifugation for $5 \mathrm{~min}$ at $8,000 \times \mathrm{g}$. DNA was precipitated by addition of $10 \% 3 \mathrm{M}$ sodium acetate $(\mathrm{pH} 5.2)$ and 1 volume isopropanol to the solution, followed by centrifugation for $5 \mathrm{~min}$ at 13,000 $\times \mathrm{g}$. Pelleted DNA was rinsed with $70 \%$ ethanol, centrifuged at $13,000 \times g$ for $5 \mathrm{~min}$, air-dried, rinsed with $95-100 \%$ ethanol, centrifuged, air-dried, and suspended in 150-200 $\mu \mathrm{L}$ TE buffer (10 mM Tris, $1 \mathrm{mM}$ EDTA, $\mathrm{pH}$ 8.0). Purified DNA was stored at $-80^{\circ} \mathrm{C}$ until selected samples were shipped to Zymo Research Corp (Irvine, CA) for DNA methylation analysis.

Library construction for DNA methylation analysis. A method of reduced representation bisulfite sequencing (RRBS), Methyl-MiniSeq (Zymo Research; Irvine, CA), was used to assess differential DNA methylation in samples from PNS compared with Control bull calves. Libraries were prepared from $200-500 \mathrm{ng}$ of genomic DNA digested with 60 units of Taq $\alpha \mathrm{I}$ and 30 units of MspI (NEB) sequentially and then extracted with Zymo Research (ZR) DNA Clean \& Concentrator-5 kit (Cat\#: D4003). Fragments were ligated to preannealed adapters containing 5 -methyl-cytosine instead of cytosine according to Illumina's specified guidelines (www.illumina.com). Adaptor-ligated fragments of 150-250 bp and 250350 bp in size were recovered from a $2.5 \%$ NuSieve 1:1 agarose gel (Zymoclean Gel DNA Recovery Kit, ZR Cat\#: D4001). The fragments were then bisulfitetreated using the EZ DNA Methylation-Lightning Kit (ZR, Cat\#: D5020). Preparative-scale PCR was performed and the resulting products were purified (DNA Clean \& Concentrator - ZR, Cat\#D4005) and sequenced on an Illumina HiSeq.

Methyl-MiniSeq sequence alignments and data analysis. Sequence reads from bisulfite-treated EpiQuest libraries were identified with standard Illumina base-calling software and analyzed via a
Zymo Research proprietary analysis pipeline, which is written in Python and used Bismark (http://www. bioinformatics.babraham.ac.uk/projects/bismark/) to perform the alignment. Bismark is used to map bisulfite converted sequence reads to determine methylation status of cytosine nucleotides. Index files were constructed using the bismark_genome_ preparation command (creates a subdirectory in the fasta file directory) and the entire reference genome. The --non_directional parameter was applied while running Bismark. All other parameters were set to default. Filled-in nucleotides were trimmed off for methylation calling. Methylation ratio was defined as the measured number of cytosines (number of reads reporting a $\mathrm{C}$ ) divided by the total number of cytosines (total number of reads reporting a $\mathrm{C}$ or $\mathrm{T})$ covered at that site. Each methylation difference was calculated by subtracting the average Control methylation ratio at a site from the average PNS methylation ratio at a site. Fisher's exact test or $t$-test was performed for each $\mathrm{CpG}$ site which has at least 5 reads coverage, and promoter, gene body and $\mathrm{CpG}$ island annotations were added for each $\mathrm{CpG}$ included in the comparison.

Prediction of pathways and functions altered by prenatal stress. An enrichment analysis was executed (analyzed on April 3, 2018) using Ingenuity Pathway Analysis software (IPA; Redwood City, CA) to assess alterations to signaling pathways and biological functions in PNS compared to Control bull calves by overlaying genes with differentially methylated (i.e., at least $10 \%$ more or less methylated than Controls) $\mathrm{CpG}$ sites onto networks generated by IPA. All $P$ values ( $P$ values of overlap) for those pathways and functions were calculated using a right-tailed Fisher exact test. These measured the probability of association of the significant genes with a pathway or function group by random chance alone. Only differentially methylated CpG sites $(P \leq 0.05)$ that had a methylation difference of $\geq 10 \%$ and were located within promoter regions were utilized in the enrichment analysis. The promoter region was selected, because DNA methylation in the promoter region regulates gene activity. Specifically, increased DNA methylation within gene promoter regions has been reported to cause suppressed transcription and gene expression (Levine et al., 1991; Tate and Bird, 1993). Therefore, for the purpose of predicting alterations to signaling pathways, hypomethylation within gene promoters was assumed to result in increased gene activity, while hypermethylation within gene promoters was assumed to result in decreased gene 
activity. It is important to note that genes can be inhibitors or activators of specific cellular processes. Therefore, regulation of gene expression by increased or decreased DNA methylation can result in activation or inhibition of cellular processes, depending on the function of that specific gene. For example, gene expression that is down-regulated by increased DNA methylation in an inhibitory gene could result in activation of a cellular process.

\section{RESULTS AND DISCUSSION}

\section{Genome-wide DNA Methylation in PNS and Control Bull Calves}

Coverage summary. Samples from Control and PNS calves had an average total read number of 38,534,348 and 34,894,063 read pairs, respectively. Both Control and PNS samples had an average mapping efficiency of 33\% and bisulfite conversion rate of $99 \%$. Sequence depths of unique $\mathrm{CpG}$ sites were 6,392,121 (9.0 times) for samples from Control and 6,358,081 (8.2 times) for samples from PNS bull calves on average. Sequence depths of unique CHG sites were 11,046,912 (7.3 times) for samples from Control and 10,985,061 (6.6 times) for samples from PNS bull calves on average. Sequence depths of unique $\mathrm{CHH}$ sites were 27,388,851 (6.9 times) for samples from Control and 27,218,778 (6.3 times) for samples from PNS bull calves on average.

$C p G$ sites. A summary of genome-wide distribution of differential DNA methylation in $\mathrm{CpG}$ sites (i.e., in the $\mathrm{CpG}$ context; defined as a cytosine followed by a guanine) across promoters, introns, exons, and intergenic regions in PNS compared with Control bull calves is located in Table 1. Briefly, 16,128 CpG sites $(52.76 \%$ of which were located within $\mathrm{CpG}$ islands) were differentially methylated in PNS compared to Control bull calves $(P \leq 0.05)$. The majority of differentially methylated $\mathrm{CpG}$ sites were found in intergenic regions $(65.5 \%)$, followed by introns $(19.2 \%)$, exons $(7.8 \%)$, and promoters (7.5\%). Of those affected sites, $45.93 \%$ were hypermethylated (at least 10\% more methylated than Controls; $P \leq 0.05$ ) and $54.07 \%$ were hypomethylated (at least 10\% less methylated than Controls; $P \leq 0.05)$. Methylation of DNA in mammals primarily occurs within $\mathrm{CpG}$ contexts (Ehrlich et al., 1982), although reports of substantial DNA methylation within non-CpG contexts (i.e., in the $\mathrm{CHG}$ or $\mathrm{CHH}$ context; in which $\mathrm{C}=$ cytosine; $\mathrm{G}=$ guanine; $\mathrm{H}=$ either adenine, thymine, or cytosine) have been established in embryonic stem cells, gametes, and brain cells (Ramsahoye et al., 2000; Shirane et al., 2013; Varley et al., 2013). Previously, methylation of cytosine nucleotides in non-CPG contexts was thought to vanish upon cellular differentiation (Lister et al., 2009). However, methylation of DNA in non- $\mathrm{CpG}$ contexts of differentiated mammalian cell types has gained attention in various tissues in recent years (Ziller et al., 2011; Barua et al., 2014; Zhou et al., 2016).

Non- $C p G$ sites. A summary of genome-wide distribution of differential DNA methylation in $\mathrm{CHG}$ sites across promoters, introns, exons, and intergenic regions in PNS compared with Control bull calves is located in Table 1. Briefly, 226 CHG sites (20.28\% of which were located within $\mathrm{CpG}$ islands) were differentially methylated in PNS compared to Control bull calves $(P \leq 0.05)$. The majority of differentially methylated $\mathrm{CHG}$ sites were found in intergenic regions $(64.6 \%)$, followed by introns $(24.3 \%)$, exons $(6.6 \%)$, and promoters $(4.4 \%)$. Of those affected sites, $47.79 \%$ were hypermethylated and $52.21 \%$ were hypomethylated.

A summary of genome-wide distribution of differential DNA methylation in $\mathrm{CHH}$ sites across promoters, introns, exons, and intergenic regions in PNS compared with Control bull calves is located in Table 1. Briefly, $391 \mathrm{CHH}$ sites $(15.20 \%$ of which were located within $\mathrm{CpG}$ islands) were differentially methylated in PNS compared to Control bull calves $(P \leq 0.05)$. The majority of differentially methylated $\mathrm{CHH}$ sites were found in intergenic regions $(62.4 \%)$, followed by introns $(30.9 \%)$, promoters $(3.6 \%)$, and exons $(3.1 \%)$. Of those affected sites, $53.45 \%$ were hypermethylated and $46.55 \%$ were hypomethylated.

Zhou et al. (2016) assessed DNA methylation of 10 bovine cell types using RRBS and found that of the $\mathrm{CpG}$-enriched regions, 33.5\% were in the $\mathrm{CpG}$ context, $1.1 \%$ were in the $\mathrm{CHG}$ context, and $1.5 \%$ were in the $\mathrm{CHH}$ context. Of the cytosines that were differentially methylated compared to one or more of the other 10 cell types, $94.34 \%$ were in the $\mathrm{CpG}$ context and $5.66 \%$ were in the non-CpG context (Zhou et al., 2016). Furthermore, Barua et al. (2014) reported differential methylation of $\mathrm{CHG}$ and $\mathrm{CHH}$ contexts due to prenatal programming in rodents. Thus, increasing evidence suggests an influence of DNA methylation in non-CpG contexts in differentiated mammalian cells.

\section{Differential DNA Methylation in CpG Sites}

Promoter regions. A total of 1,205 differentially methylated $\mathrm{CpG}$ sites were identified within promoter regions in PNS compared with Control bull 
Table 1. Summary of genome-wide distribution of differential DNA methylation (HYPER= Hypermethylation, $\mathrm{HYPO}=$ Hypomethylation) across $\mathrm{CpG}, \mathrm{CHG}$, and $\mathrm{CHH}$ sites in prenatally stressed (PNS) compared with Control bull calves ${ }^{1,2,3}$

\begin{tabular}{|c|c|c|c|c|c|c|c|c|c|c|}
\hline Genomic region & $\begin{array}{l}\text { Affected } \\
\text { regions } \\
(N)\end{array}$ & $\begin{array}{l}\text { Percent of } \\
\text { total regions } \\
\text { affected }\end{array}$ & $\begin{array}{l}\text { HYPER } \\
\text { regions } \\
(N)\end{array}$ & $\begin{array}{l}{ }^{4} \text { Percent } \\
\text { of affected } \\
\text { regions with } \\
\text { HYPER }\end{array}$ & $\begin{array}{l}\text { HYPO } \\
\text { regions } \\
(N)\end{array}$ & $\begin{array}{l}\text { Percent of } \\
\text { affected } \\
\text { regions with } \\
\text { HYPO }\end{array}$ & $\begin{array}{c}\text { HYPER } \\
\text { regions } \\
\text { within CpG } \\
\text { Islands }(N)\end{array}$ & $\begin{array}{c}\text { Percent of } \\
\text { HYPER } \\
\text { regions } \\
\text { within CpG } \\
\text { Islands }\end{array}$ & $\begin{array}{c}\text { HYPO } \\
\text { regions } \\
\text { within CpG } \\
\text { Islands }(N)\end{array}$ & $\begin{array}{c}\text { Percent } \\
\text { of HYPO } \\
\text { regions } \\
\text { within CpG } \\
\text { Islands }\end{array}$ \\
\hline \multicolumn{11}{|l|}{ CpG Sites } \\
\hline Promoter & 1,205 & $7.5 \%$ & 543 & $3.37 \%$ & 662 & $4.10 \%$ & 307 & $4.14 \%$ & 364 & $4.17 \%$ \\
\hline Intron & 3,103 & $19.2 \%$ & 1,386 & $8.59 \%$ & 1,717 & $10.65 \%$ & 303 & $4.09 \%$ & 354 & $4.06 \%$ \\
\hline Exon & 1,260 & $7.8 \%$ & 602 & $3.73 \%$ & 658 & $4.08 \%$ & 364 & $4.91 \%$ & 383 & $4.39 \%$ \\
\hline Intergenic & 10,560 & $65.5 \%$ & 4,876 & $30.23 \%$ & 5,684 & $35.24 \%$ & 1,025 & $13.84 \%$ & 1,146 & $13.14 \%$ \\
\hline Total & 16,128 & $100.0 \%$ & 7,407 & $45.93 \%$ & 8,721 & $54.07 \%$ & 1,999 & $26.99 \%$ & 2,247 & $25.77 \%$ \\
\hline \multicolumn{11}{|l|}{ CHG Sites } \\
\hline Promoter & 10 & $4.4 \%$ & 3 & $1.33 \%$ & 7 & $3.10 \%$ & 1 & $0.93 \%$ & 2 & $1.69 \%$ \\
\hline Intron & 55 & $24.3 \%$ & 28 & $12.39 \%$ & 27 & $11.95 \%$ & 1 & $0.93 \%$ & 2 & $1.69 \%$ \\
\hline Exon & 15 & $6.6 \%$ & 9 & $3.98 \%$ & 6 & $2.65 \%$ & 3 & $2.78 \%$ & 2 & $1.69 \%$ \\
\hline Intergenic & 146 & $64.6 \%$ & 68 & $30.09 \%$ & 78 & $34.51 \%$ & 5 & $4.63 \%$ & 7 & $5.93 \%$ \\
\hline Total & 226 & $100.0 \%$ & 108 & $47.79 \%$ & 118 & $52.21 \%$ & 10 & $9.26 \%$ & 13 & $11.02 \%$ \\
\hline \multicolumn{11}{|l|}{ CHH Sites } \\
\hline Promoter & 14 & $3.6 \%$ & 6 & $1.53 \%$ & 8 & $2.05 \%$ & 2 & $0.96 \%$ & 1 & $0.55 \%$ \\
\hline Intron & 121 & $30.9 \%$ & 65 & $16.62 \%$ & 56 & $14.32 \%$ & 4 & $1.91 \%$ & 5 & $2.75 \%$ \\
\hline Exon & 12 & $3.1 \%$ & 6 & $1.53 \%$ & 6 & $1.53 \%$ & 2 & $0.96 \%$ & 1 & $0.55 \%$ \\
\hline Intergenic & 244 & $62.4 \%$ & 132 & $33.76 \%$ & 112 & $28.64 \%$ & 10 & $4.78 \%$ & 5 & $2.75 \%$ \\
\hline Total & 391 & $100.00 \%$ & 209 & $53.45 \%$ & 182 & $46.55 \%$ & 18 & $8.61 \%$ & 12 & $6.59 \%$ \\
\hline
\end{tabular}

${ }^{1}$ Affected regions were considered $P \leq 0.05$.

${ }^{2}$ In limited cases, multiple genes were represented within one recorded region. In such cases, the record was considered one site.

${ }^{3}$ Differentially methylated sites were at least $10 \%$ more or less methylated than Controls.

${ }^{4}$ Percent of hypermethylated regions and percent of hypomethylated regions add up to $100 \%$.

calves (Table 1). A greater percentage of these $\mathrm{CpG}$ sites were hypomethylated $(54.07 \%)$ compared to hypermethylated (45.93\%; Table 1). Richetto et al. (2017) reported a similar occurrence in mice that were exposed to a prenatal viral challenge on gestational day 9 or 17 , with $64 \%$ and $61 \%$ of differentially methylated regions being hypomethylated and $36 \%$ and $39 \%$ being hypermethylated, respectively. Differential methylation within promoter regions in PNS compared with Control bulls was distributed throughout the genome, with all chromosomes having both hypomethylated and hypermethylated $\mathrm{CpG}$ sites (Fig. 1). The number of hypermethylated compared with hypomethylated $\mathrm{CpG}$ sites within promoter regions in PNS compared with Control bulls is represented in Fig. 1. Increased DNA methylation within gene promoter regions has been reported to cause suppressed transcription and gene expression (Levine et al., 1991; Tate and Bird, 1993). This suggests that hypermethylated $\mathrm{CpG}$ sites within gene promoter regions might have downregulated gene expression and hypomethylated $\mathrm{CpG}$ sites within gene promoter regions might have upregulated gene expression in PNS calves compared with Controls.

Strongly differentially methylated $\mathrm{CpG}$ sites ("strongly" being defined as a degree of methylation in PNS calves that was at least 33\% different from Controls) were specifically examined to highlight those sites that exhibited the greatest changes in degree of methylation due to PNS treatment. In agreement with this study's overall findings, a greater percentage of strongly hypomethylated (methylation difference $\leq-0.33$ ratio) compared to strongly hypermethylated (methylation difference $\geq 0.33$ ratio) $\mathrm{CpG}$ sites were identified within promoter regions $(P \leq 0.05)$ in PNS bull calves compared with Controls. Six strongly hypermethylated $\mathrm{CpG}$ sites were located within promoter regions in PNS compared with Control calves (Table 2). Among these were $2 \mathrm{CpG}$ sites that were located within the promoter region of the NQO2 gene. This hypermethylated gene was also involved in the upregulation of the "NRF2-mediated Oxidative Stress Response" pathway in PNS calves (Supplementary Table S1). Furthermore, a base pair deletion in the promoter region of this gene 


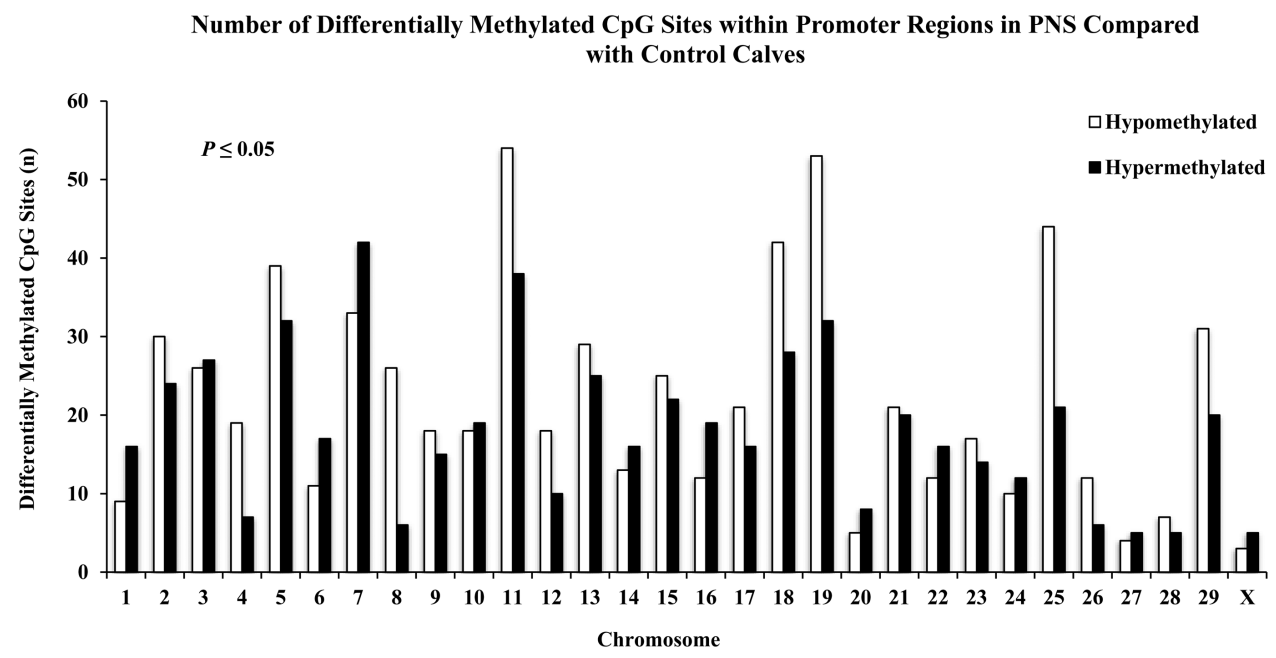

Figure 1. Comparison of hypermethylated and hypomethylated $\mathrm{CpG}$ sites within promoter regions in prenatally stressed (PNS) compared with Control bull calves.

Table 2. Strongly hypermethylated (methylation difference $\geq 0.33$ ratio) $\mathrm{CpG}$ sites located within promoter regions of genes in prenatally stressed (PNS) compared with Control calves ${ }^{1}$

\begin{tabular}{|c|c|c|c|c|c|c|c|c|}
\hline Chrom & Gene & Start & End & Strand & $\begin{array}{l}\text { Average Total } \\
\text { CPG (Control) }\end{array}$ & $\begin{array}{c}\text { Average Total } \\
\text { CPG (PNS) }\end{array}$ & $\begin{array}{l}\text { Methyl } \\
\text { Diff }\end{array}$ & $P$ value \\
\hline$\overline{\operatorname{chr} 7^{\dagger}}$ & $C C D C 105$ & 9178140 & 9178141 & - & 7.86 & 8.71 & 0.36 & 0.003097 \\
\hline $\operatorname{chr} 11^{\dagger^{*}}$ & $M R P L 41$ & 105596122 & 105596123 & - & 8.57 & 7.00 & 0.35 & 0.003315 \\
\hline $\operatorname{chr} 12^{\dagger}$ & PCDH17 & 5200175 & 5200176 & - & 11.14 & 7.29 & 0.34 & 0.0004446 \\
\hline $\operatorname{chr} 21^{*}$ & MIR655 & 67587446 & 67587447 & + & 8.57 & 9.43 & 0.45 & 0.008982 \\
\hline chr23 & NQO2 & 50497771 & 50497772 & - & 6.71 & 5.86 & 0.39 & 0.002682 \\
\hline $\operatorname{chr} 23^{\dagger}$ & NQO2 & 50497904 & 50497905 & - & 6.71 & 5.86 & 0.42 & 0.02622 \\
\hline
\end{tabular}

${ }^{1}$ In limited cases, multiple genes were represented within one recorded region. In such cases, the record was considered one site. "DNA methylation was located within a CPG island.

"DNA methylation was exclusively located within the promoter region.

has been associated with schizophrenia in humans (Harada et al., 2003), suggesting the potential for physiological and behavioral alterations due to differences in neurotransmitter pathways.

The top (lowest $P$ values) 30 of 543 significantly $(P \leq 0.05)$ hypermethylated $\mathrm{CpG}$ sites located within promoter regions in PNS compared with Control calves are listed in Table 3. Among these was a $\mathrm{CpG}$ site within the promoter region of the Caudal Type Homeobox 2 (CDX2) gene. $C D X 2$ is involved in early embryo pluripotency, differentiation, and development (Xie et al., 2013). Therefore, it is consistent that this gene was also involved in the alterations to the pathways, "Role of NANOG in Mammalian Embryonic Stem Cell Pluripotency, Transcriptional Regulatory Network in Embryonic Stem Cells, Role of Oct4 in Mammalian Embryonic Stem Cell Pluripotency" in PNS calves (Supplementary Table S1). In vitro hyperosmolar stress resulted in reduced $C D X 2$ and inhibited potency in the early embryo of the mouse (Xie et al., 2013). Bovine embryos exposed to heat stress exhibited reduced $C D X 2$ gene expression in total blastocyst RNA (Silva et al., 2013). These studies agree with the current study, which is predictive of downregulated expression of $C D X 2$ due to increased DNA methylation in the promoter region of $C D X 2$ in PNS bulls compared with Controls.

There were 22 strongly hypomethylated $\mathrm{CpG}$ sites located within promoter regions in PNS compared with Control calves (Table 4). Among these was a $\mathrm{CpG}$ site within the promoter region of the Guanine Nucleotide-Binding Protein G(S) Subunit Alpha $(\boldsymbol{G N} \boldsymbol{A S})$ gene. In cattle and other mammals, GNAS is an imprinted gene that has been reported to play a major role in development, growth, and metabolism (Plagge et al., 2004; Sikora et al., 2011). DNA methylation of a paternally expressed transcript of this gene, GNASXL, has been reported to be positively associated with prenatal maternal stress (as quantified by increased depression, anxiety, and cortisol) in humans (Vangeel et al., 2015). This is in contrast with the hypomethylated $\mathrm{CpG}$ site within the promoter region of the GNAS gene in PNS bull calves in this study. 
Table 3. Top (lowest $P$ values) 30 hypermethylated $\mathrm{CpG}$ sites located within promoter regions of genes in prenatally stressed (PNS) compared with Control calves ${ }^{1}$

\begin{tabular}{|c|c|c|c|c|c|c|c|c|}
\hline Chrom & Gene & Start & End & Strand & $\begin{array}{l}\text { Average Total } \\
\text { CPG (Control) }\end{array}$ & $\begin{array}{c}\text { Average Total } \\
\text { CPG (PNS) }\end{array}$ & $\begin{array}{c}\text { Methyl } \\
\text { Diff }\end{array}$ & $P$ value \\
\hline$\overline{\operatorname{chr} 1^{\dagger}}$ & CLSTN2 & 130108179 & 130108180 & - & 11.71 & 13.00 & 0.11 & 0.000009504 \\
\hline chr1 & $C L D N 8$ & 5036161 & 5036162 & + & 16.57 & 14.29 & 0.13 & 0.0003032 \\
\hline $\operatorname{chr} 2^{\dagger}$ & TMEM200B & 125008770 & 125008771 & + & 12.43 & 9.71 & 0.13 & 0.00028 \\
\hline $\operatorname{chr} 3^{+}$ & SHE & 16143944 & 16143945 & + & 7.14 & 12.29 & 0.18 & 0.0009009 \\
\hline $\operatorname{chr} 7^{\dagger}$ & $H N R N P M$ & 18289571 & 18289572 & - & 9.43 & 8.71 & 0.21 & 0.0002804 \\
\hline $\operatorname{chr} 7^{\dagger}$ & $H N R N P M$ & 18289557 & 18289558 & - & 9.43 & 8.71 & 0.22 & 0.0006671 \\
\hline $\operatorname{chr} 7$ & SIL1 & 52143957 & 52143958 & + & 13.00 & 10.71 & 0.1 & 0.001113 \\
\hline $\operatorname{chr} 7^{\dagger}$ & $H N R N P M$ & 18289508 & 18289509 & - & 9.43 & 8.57 & 0.21 & 0.001569 \\
\hline $\operatorname{chr} 7^{\dagger}$ & $H N R N P M$ & 18289493 & 18289494 & - & 9.29 & 8.71 & 0.22 & 0.001877 \\
\hline $\operatorname{chr} 7^{\dagger}$ & $H N R N P M$ & 18289497 & 18289498 & - & 9.43 & 8.71 & 0.22 & 0.001877 \\
\hline $\operatorname{chr} 7^{\dagger}$ & $H N R N P M$ & 18289505 & 18289506 & - & 9.43 & 8.71 & 0.22 & 0.001877 \\
\hline $\operatorname{chr} 10^{*}$ & EIF3J & 103983752 & 103983753 & + & 9.43 & 8.86 & 0.13 & $6.067 \mathrm{E}-07$ \\
\hline $\operatorname{chr} 10^{\dagger^{* *}}$ & SIX6 & 72952940 & 72952941 & - & 13.00 & 10.14 & 0.19 & 0.0001318 \\
\hline $\operatorname{chr} 10^{\dagger}$ & SHC4 & 61503850 & 61503851 & + & 8.86 & 9.14 & 0.17 & 0.001072 \\
\hline $\operatorname{chr} 10^{*}$ & EIF3J & 103983746 & 103983747 & + & 9.29 & 8.86 & 0.14 & 0.001454 \\
\hline $\operatorname{chr} 10$ & SHC4 & 61504208 & 61504209 & - & 9.86 & 7.29 & 0.15 & 0.001506 \\
\hline $\operatorname{chr} 10^{\dagger}$ & LHFPL2 & 9527046 & 9527047 & + & 13.00 & 8.86 & 0.11 & 0.001618 \\
\hline chr11 & $B R E, R B K S$ & 71827429 & 71827430 & - & 12.14 & 10.86 & 0.3 & 0.0007929 \\
\hline $\operatorname{chr} 12^{*}$ & $C D X 2$ & 32316737 & 32316738 & - & 18.86 & 13.00 & 0.25 & 0.0002012 \\
\hline $\operatorname{chr} 12^{\dagger}$ & PCDH17 & 5200175 & 5200176 & - & 11.14 & 7.29 & 0.34 & 0.0004446 \\
\hline $\operatorname{chr} 13^{\dagger}$ & $B M P 7$ & 59425545 & 59425546 & - & 8.00 & 8.00 & 0.11 & 0.001394 \\
\hline $\operatorname{chr} 15$ & $M M P 7$ & 6390211 & 6390212 & + & 8.57 & 6.29 & 0.19 & 0.000205 \\
\hline $\operatorname{chr} 15^{\dagger}$ & CHRM4 & 77253713 & 77253714 & + & 10.71 & 6.14 & 0.13 & 0.000309 \\
\hline $\operatorname{chr} 16^{* *}$ & $M M P 23 B$ & 52263865 & 52263866 & + & 10.71 & 8.86 & 0.12 & 0.001214 \\
\hline $\operatorname{chr} 16^{\dagger^{*}}$ & $S L C 45 A 1$ & 45908696 & 45908697 & - & 11.57 & 9.00 & 0.11 & 0.001281 \\
\hline chr19 & $I T G A 3$ & 37230331 & 37230332 & + & 12.29 & 11.00 & 0.12 & 0.0000896 \\
\hline $\operatorname{chr} 19^{*}$ & CORO6 & 21435132 & 21435133 & + & 21.00 & 18.00 & 0.17 & 0.001546 \\
\hline $\operatorname{chr} 25^{\dagger}$ & METRN & 613852 & 613853 & - & 8.71 & 6.00 & 0.12 & 0.001253 \\
\hline chr26 & ZWINT & 2851210 & 2851211 & + & 10.00 & 11.71 & 0.15 & 0.0001167 \\
\hline $\operatorname{chr} 28^{\dagger}$ & TRIM67 & 3519622 & 3519623 & + & 18.14 & 19.14 & 0.11 & 0.001037 \\
\hline
\end{tabular}

${ }^{1}$ In limited cases, multiple genes were represented within one recorded region. In such cases, the record was considered one site.

'DNA methylation was located within a CPG island.

*DNA methylation was exclusively located within the promoter region.

The top (lowest $P$ values) 30 of 662 significantly $(P \leq 0.05)$ hypomethylated $\mathrm{CpG}$ sites located within promoter regions in PNS compared with Control calves are listed in Table 5. Among these was a $\mathrm{CpG}$ site within the promoter region of the Dopamine Receptor D1 (DRD1) gene. This gene has been associated with behavioral disorders such as psychosis and schizophrenia (Andreou et al., 2016). The DRD1 gene was involved in the following pathways altered in PNS calves in this study: "cAMP-mediated signaling, G-Protein Coupled Receptor Signaling, Gas Signaling, DopamineDARPP32 Feedback in cAMP Signaling, CDK5 Signaling, Gap Junction Signaling, and Dopamine Receptor Signaling" (Supplementary Table S1). Rat pups that were separated from their mothers for 6-h periods each day during the first $2 \mathrm{wk}$ of life had downregulated $D R D 1$ gene expression in the nucleus accumbens (Zhu et al., 2010). Rat pups that were separated from their mothers for 3 -h periods had decreased mid-brain tyrosine hydroxylase-immunoreactive dopaminergic neurons as juveniles (15 d of age) but increased numbers as adolescents (35 d of age) and adults ( $70 \mathrm{~d}$ of age; Chocyk et al., 2011). These varying results suggest that alterations to the $D R D 1$ gene due to prenatal or early life stress are specific to life stage.

Gene body regions. Differential methylation of 4,363 CpG sites were identified within gene body (i.e., introns and exons) regions in PNS compared with Control bull calves (Table 1). A greater percentage of these $\mathrm{CpG}$ sites were hypomethylated (Table 1). Differential methylation within gene body regions in PNS compared with Control bulls was distributed throughout the genome, with both 
Table 4. Strongly hypomethylated (methylation difference $\leq-0.33$ ratio) $\mathrm{CpG}$ sites located within promoter regions of genes in prenatally stressed (PNS) compared with Control calves ${ }^{1}$

\begin{tabular}{|c|c|c|c|c|c|c|c|c|}
\hline Chrom & Gene & Start & End & Strand & $\begin{array}{l}\text { Average Total } \\
\text { CPG (Control) }\end{array}$ & $\begin{array}{c}\text { Average Total } \\
\text { CPG (PNS) }\end{array}$ & $\begin{array}{l}\text { Methyl } \\
\text { Diff }\end{array}$ & $P$ value \\
\hline chr1 $1^{*}$ & $E P C A M$ & 157207666 & 157207667 & - & 7.4 & 8.9 & -0.34 & 0.0495 \\
\hline $\operatorname{chr} 1^{\dagger *}$ & $G N A S$ & 154101009 & 154101010 & - & 10.6 & 5.4 & -0.35 & 0.0147 \\
\hline $\operatorname{chr} 7^{*}$ & TNFRSF10D & 18053077 & 18053078 & - & 10.9 & 16.0 & -0.38 & 0.01531 \\
\hline $\operatorname{chr} 8$ & $K H N Y N, C B L N 3$ & 104517901 & 104517902 & - & 11.9 & 9.0 & -0.35 & 0.03365 \\
\hline chr9 & $P L A 2 G 4 B$ & 103674611 & 103674612 & + & 14.7 & 6.9 & -0.44 & 0.04478 \\
\hline chr11 & $A T F 6 B$ & 103182975 & 103182976 & + & 13.7 & 9.4 & -0.33 & 0.002325 \\
\hline $\operatorname{chr} 11^{\dagger}$ & SNX19 & 100835712 & 100835713 & - & 8.0 & 11.4 & -0.35 & 0.006669 \\
\hline $\operatorname{chr} 13^{\dagger}$ & LOXL4 & 58167618 & 58167619 & - & 12.7 & 12.4 & -0.34 & 0.01073 \\
\hline $\operatorname{chr} 13^{\dagger}$ & $M G R N 1$ & 58167617 & 58167618 & + & 11.3 & 23.0 & -0.33 & 0.004263 \\
\hline $\operatorname{chr} 13^{\dagger}$ & $Y D J C$ & 54817882 & 54817883 & - & 6.7 & 10.9 & -0.39 & 0.007604 \\
\hline $\operatorname{chr} 17^{\dagger}$ & $Y D J C$ & 73172496 & 73172497 & - & 7.3 & 12.0 & -0.45 & 0.009104 \\
\hline $\operatorname{chr} 19$ & $A T F 6 B$ & 22423681 & 22423682 & - & 14.3 & 14.0 & -0.38 & 0.01513 \\
\hline $\operatorname{chr} 20^{*}$ & CSNKID & 69935936 & 69935937 & - & 9.0 & 9.4 & -0.39 & 0.01086 \\
\hline $\operatorname{chr} 21^{\dagger^{*}}$ & GNAS & 30886861 & 30886862 & - & 11.3 & 9.6 & -0.33 & 0.01602 \\
\hline $\operatorname{chr} 23^{\dagger}$ & $M G R N 1$ & 51619275 & 51619276 & - & 11.0 & 8.6 & -0.33 & 0.004263 \\
\hline $\operatorname{chr} 23^{\dagger}$ & $S N X 19$ & 17940352 & 17940353 & - & 9.4 & 11.1 & -0.35 & 0.02976 \\
\hline $\operatorname{chr} 23^{\dagger}$ & TMODI & 51239299 & 51239300 & + & 11.6 & 9.0 & -0.35 & 0.0389 \\
\hline $\operatorname{chr} 23^{*}$ & $U B X N 8$ & 48211861 & 48211862 & - & 10.9 & 6.3 & -0.37 & 0.001421 \\
\hline $\operatorname{chr} 24^{\dagger}$ & $M G R N 1$ & 3104521 & 3104522 & - & 10.9 & 7.0 & -0.33 & 0.004263 \\
\hline $\operatorname{chr} 25^{*}$ & $C A R D 9$ & 1721752 & 1721753 & - & 9.7 & 9.7 & -0.34 & 0.002587 \\
\hline $\operatorname{chr} 25$ & $\begin{array}{l}\text { MIR99B, } \\
\quad \text { MIRLET7E }\end{array}$ & 4471948 & 4471949 & + & 8.4 & 6.3 & -0.38 & 0.005474 \\
\hline $\operatorname{chr} 25^{*}$ & TNFRSF10D & 2238087 & 2238088 & + & 12.3 & 9.1 & -0.37 & 0.02807 \\
\hline
\end{tabular}

${ }^{1}$ In limited cases, multiple genes were represented within one recorded region. In such cases, the record was considered one site.

DNA methylation was located within a CPG island.

*DNA methylation was exclusively located within the promoter region.

hypomethylation and hypermethylation observed in $\mathrm{CpG}$ sites across all chromosomes (Fig. 2). The number of hypermethylated compared with hypomethylated $\mathrm{CpG}$ sites within gene body regions in PNS compared with Control bulls are represented in Fig. 2. Increased DNA methylation in gene bodies may result in activated gene expression (Hellman and Chess, 2007), suggesting that hypermethylated gene body regions might have upregulated gene expression and hypomethylated gene body regions might have downregulated gene expression.

The top (lowest $P$ values) 30 of 1,988 significantly $(P \leq 0.05)$ hypermethylated $\mathrm{CpG}$ sites located within gene body regions in PNS compared with Control calves are listed in Table 6 . Among these was a $\mathrm{CpG}$ site within the gene body region of the Iodothyronine Deiodinase 3 (DIO3) gene, suggesting a potential upregulation in gene expression. The DIO3 gene is an imprinted gene in mice, cattle, and other species that encodes a protein, which inactivates thyroid hormones (Tsai et al., 2002; Yang et al., 2017). Thyroid hormones influence central nervous system development
(Bernal, 2005) and behavior (Stohn et al., 2018). Male and female mice deficient in DIO3 exhibited increased aggression in response to an intruder (Stohn et al., 2018). Furthermore, rats whose dams consumed ethanol from day 8 to 21 of gestation had increased placental DIO3 mRNA compared to Controls (Shukla et al., 2011). These studies suggest that prenatal environment can shape nervous system development through alterations to the DIO3 gene.

The top (lowest $P$ values) 30 of 2,375 significantly $(P \leq 0.05)$ hypomethylated $\mathrm{CpG}$ sites located within gene body regions in PNS compared with Control calves are listed in Table 7. Among these was a $\mathrm{CpG}$ site within the gene body region of the Adenylate Cyclase Activating Polypeptide 1 (ADCYAP1) gene, suggesting a potential downregulation in gene expression. The $A D C Y A P 1$ gene encodes for the PACAP peptide and is associated with stress disorders and posttraumatic stress disorder (Ressler et al., 2011). Mice that were deficient in PACAP exhibited behavioral abnormalities such as hyperactivity, jumping, and depression 
Table 5. Top (lowest $P$ values) 30 hypomethylated $\mathrm{CpG}$ sites located within promoter regions of genes in prenatally stressed (PNS) compared with Control calves ${ }^{1}$

\begin{tabular}{|c|c|c|c|c|c|c|c|c|}
\hline Chrom & Gene & Start & End & Strand & $\begin{array}{l}\text { Average Total } \\
\text { CPG (Control) }\end{array}$ & $\begin{array}{l}\text { Average Total } \\
\text { CPG (PNS) }\end{array}$ & $\begin{array}{l}\text { Methyl } \\
\text { Diff }\end{array}$ & $P$ value \\
\hline $\operatorname{chr}^{\dagger}$ & $E C H D C 2$ & 94016695 & 94016696 & + & 9.14 & 12.29 & -0.28 & 0.0006247 \\
\hline $\operatorname{chr} 4^{\dagger}$ & OSBPL3 & 71296952 & 71296953 & + & 17.29 & 15.57 & -0.13 & 0.001308 \\
\hline $\operatorname{chr} 7$ & $F D X 1 L$ & 16072432 & 16072433 & + & 9.43 & 9.57 & -0.18 & 0.0004641 \\
\hline $\operatorname{chr} 7^{\dagger}$ & $N M R K 2$ & 21294100 & 21294101 & + & 10.00 & 7.43 & -0.16 & 0.000824 \\
\hline chr8 & $\begin{array}{c}\text { MIR2887-2, MIR2887-1, } \\
\text { MIR2904-1, MIR2904-3, MIR2904-2 }\end{array}$ & 59158057 & 59158058 & + & 9.71 & 13.57 & -0.23 & 0.0008405 \\
\hline $\operatorname{chr} 8^{\dagger *}$ & XKR6 & 8255834 & 8255835 & - & 14.57 & 7.43 & -0.11 & 0.001542 \\
\hline chr9* & SEC63 & 42650623 & 42650624 & + & 14.14 & 9.29 & -0.17 & 0.0002254 \\
\hline $\operatorname{chr} 9$ & $O P R M 1$ & 92152196 & 92152197 & + & 8.14 & 9.43 & -0.13 & 0.0002767 \\
\hline chr9 & $O P R M 1$ & 92152194 & 92152195 & + & 8.14 & 9.43 & -0.2 & 0.001245 \\
\hline $\operatorname{chr} 10^{*}$ & $D R D 1$ & 5653417 & 5653418 & + & 9.14 & 7.86 & -0.19 & 0.0003017 \\
\hline $\operatorname{chr} 10$ & $L T B 4 R$ & 20689223 & 20689224 & - & 8.43 & 9.86 & -0.16 & 0.0007834 \\
\hline $\operatorname{chr} 11^{\dagger}$ & SIX2 & 27263419 & 27263420 & + & 21.00 & 17.00 & -0.11 & 0.0005395 \\
\hline $\operatorname{chr} 11^{\dagger^{*}}$ & SURF4 & 104335032 & 104335033 & - & 11.29 & 11.14 & -0.14 & 0.001013 \\
\hline $\operatorname{chr} 15^{\dagger}$ & $A P L N R$ & 81738036 & 81738037 & + & 25.57 & 24.57 & -0.23 & 0.0004384 \\
\hline $\operatorname{chr} 18^{*}$ & $E G L N 2$ & 50330819 & 50330820 & - & 8.00 & 6.57 & -0.15 & 0.0007258 \\
\hline $\operatorname{chr} 18^{\dagger^{*}}$ & NAT14 & 62474955 & 62474956 & - & 11.57 & 10.86 & -0.25 & 0.001256 \\
\hline $\operatorname{chr} 18$ & $F U Z$ & 56625931 & 56625932 & - & 10.57 & 8.43 & -0.3 & 0.001281 \\
\hline $\operatorname{chr} 19^{\dagger}$ & PMP22 & 33382476 & 33382477 & - & 11.43 & 12.57 & -0.12 & 0.00007101 \\
\hline chr19 & $E R B B 2$ & 40722503 & 40722504 & + & 13.14 & 9.57 & -0.1 & 0.0004212 \\
\hline $\operatorname{chr} 19^{*}$ & $M P D U 1$ & 27924874 & 27924875 & - & 8.14 & 6.57 & -0.15 & 0.001674 \\
\hline $\operatorname{chr} 21^{\dagger^{* *}}$ & $N K X 2-8$ & 47199004 & 47199005 & + & 12.86 & 14.86 & -0.24 & 0.0003029 \\
\hline $\operatorname{chr} 21^{*}$ & CHRNA7 & 30181352 & 30181353 & - & 11.00 & 7.29 & -0.29 & 0.0005365 \\
\hline $\operatorname{chr} 21^{\dagger}$ & CSPG4 & 33574762 & 33574763 & - & 7.14 & 6.86 & -0.17 & 0.00072 \\
\hline $\operatorname{chr} 22^{\dagger}$ & $I T G A 9$ & 10946832 & 10946833 & - & 17.00 & 17.43 & -0.26 & 0.001275 \\
\hline $\operatorname{chr} 25^{\dagger}$ & $P G P$ & 1746496 & 1746497 & + & 18.57 & 17.57 & -0.25 & 0.001152 \\
\hline chr26 & MIR2397 & 49743379 & 49743380 & + & 12.43 & 9.57 & -0.14 & 0.00004049 \\
\hline $\operatorname{chr} 26$ & PRLHR & 39220962 & 39220963 & + & 11.43 & 9.29 & -0.22 & 0.00008747 \\
\hline $\operatorname{chr} 27^{*}$ & $U B X N 8$ & 26008284 & 26008285 & - & 10.00 & 8.57 & -0.37 & 0.001421 \\
\hline $\operatorname{chr} 29^{*}$ & TALDO1 & 50864154 & 50864155 & - & 8.57 & 8.14 & -0.27 & 0.0001148 \\
\hline chr29* & $A P 2 A 2$ & 50445180 & 50445181 & + & 10.71 & 7.71 & -0.2 & 0.0004282 \\
\hline
\end{tabular}

${ }^{1}$ In limited cases, multiple genes were represented within one recorded region. In such cases, the record was considered one site. DNA methylation was located within a CPG island.

${ }^{*}$ DNA methylation was exclusively located within the promoter region.

(Ishihama et al., 2010). Furthermore, mice whose dams were exposed to a posttraumatic stress disorder model (restrained for $2-\mathrm{h}$ period and then forced to swim for a 20-min period with 6 other rats) had downregulated $A D C Y A P 1$ gene expression (Zhang et al., 2016). These studies support the potential influence of prenatal stress on the $A D C Y A P 1$ gene in this study and suggest altered behavioral effects due to prenatal stress. Behavioral alterations were previously observed in PNS calves (Littlejohn et al., 2016).

\section{Differential DNA Methylation in CHG Sites}

Promoter regions. There were 10 differentially methylated CHG sites within promoter regions in PNS compared with Control bull calves (Table 1).
A greater percentage of these $\mathrm{CHG}$ sites were hypomethylated compared to hypermethylated (Table 1).

The 3 significantly $(P \leq 0.05)$ hypermethylated $\mathrm{CHG}$ sites located within promoter regions in PNS compared with Control calves are listed in Table 8. Among these was a $\mathrm{CHG}$ site within the promoter region of the Crystallin Beta B3 (CRYBB3) gene. The $C R Y B B 3$ gene is a member of the crystallin gene family, dysregulations of which have been associated with neural disorders, such as Alzheimer's disease and schizophrenia (Shinohara et al., 1993; Middleton et al., 2002). Crystallin family heat shock proteins likely have a neuroprotective function (Masilamoni et al., 2006; Ousman et al., 2007). Specifically, CRYBB3 was upregulated in 3 models of mice whose dams underwent immune activation during gestation (dams were administered human 


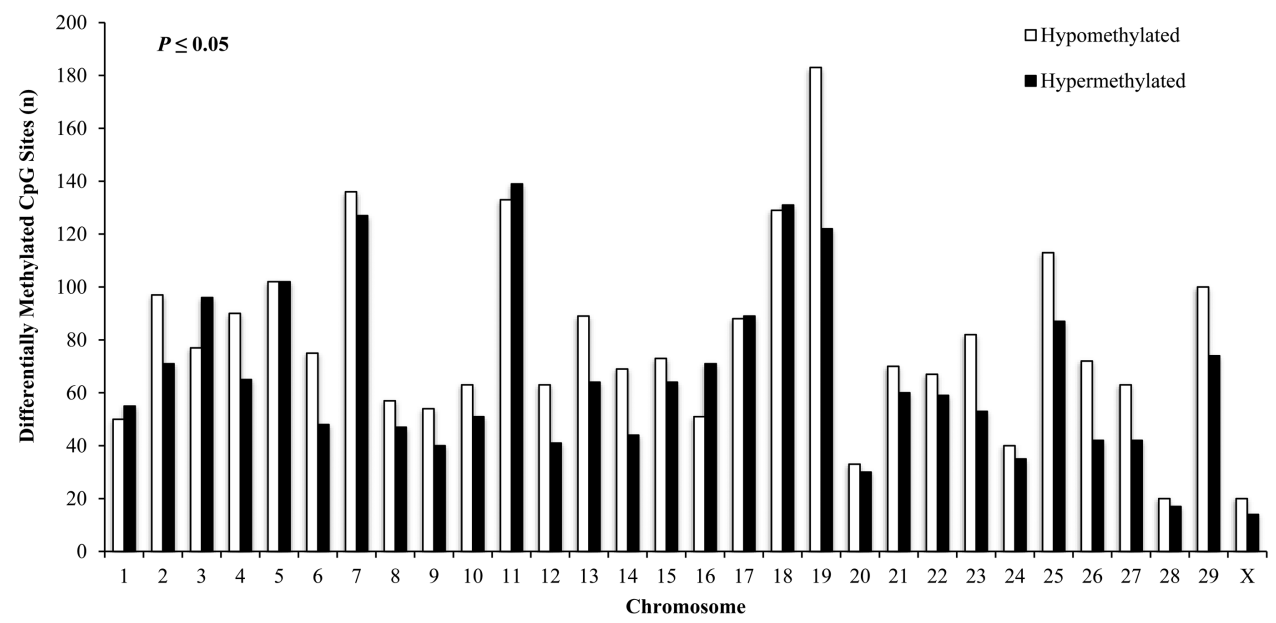

Figure 2. Comparison of hypermethylated and hypomethylated $\mathrm{CpG}$ sites within gene body regions in prenatally stressed (PNS) compared with Control bull calves.

influenza virus, poly (I:C), or recombinant IL-6 during gestation; Garbett et al., 2012). Previous studies suggest differential methylation of the $C R Y B B 3$ gene might result in alterations in neural and behavioral characteristics of PNS calves.

The 7 significant $(P \leq 0.05)$ hypomethylated CHG sites located within promoter regions in PNS compared with Control calves are listed in Table 9. Among these was a $\mathrm{CHG}$ site within the promoter region of the Coagulation Factor II Receptor-Like 3 (F2RL3) gene. The F2RL3 gene is hypomethylated in adult smokers and has been associated with mortality risk due to cardiovascular diseases (Breitling et al., 2012).

Gene body regions. There were 70 differentially methylated $\mathrm{CHG}$ sites within gene body regions in PNS compared with Control bull calves (Table 1). A slightly greater percentage of these $\mathrm{CHG}$ sites were hypermethylated compared to hypomethylated (Table 1).

The top (lowest $P$ values) 30 of 37 significantly $(P \leq 0.05)$ hypermethylated $\mathrm{CHG}$ sites located within gene body regions in PNS compared with Control calves are listed in Table 10. Among these was a $\mathrm{CHG}$ site within the gene body region of the Protein Kinase C Alpha (PRKCA) gene. The $P R K C A$ gene encodes for Protein Kinase C Alpha, a member of the serine- and threonine-specific protein kinases, which phosphorylates peptide substrates and is involved in various cell-signaling processes (Lee et al., 2017). The PRKCA gene has been associated with PTSD and memory in humans (De Quervain et al., 2012). Furthermore, rats whose dams were stressed by placing them on an elevated platform made of Plexiglass twice each day for a 10-min period between 12 and $16 \mathrm{~d}$ of gestation resulted in genome-wide alterations in gene expression, including expression of PRKCA (Mychasiuk et al., 2011). Due to its influence on various cell-signaling pathways, differential methylation of $P R K C A$ has the potential to influence many biological processes in PNS calves.

The top (lowest $P$ values) 30 of 33 significantly $(P \leq 0.05)$ hypomethylated $\mathrm{CHG}$ sites located within gene body regions in PNS compared with Control calves are listed in Table 11. Among these was a CHG site within the gene body region of the Diacylglycerol Acyltransferase 1 (DGAT1) gene. The DGAT1 gene encodes for a protein enzyme involved in the conversion of diacylglycerol and fatty acyl CoA to triacylglycerol diacylglycerol and has been associated with metabolic diseases (Yen et al., 2008) and with milk production traits in dairy cattle (Mohammed et al., 2015). Mice whose dams underwent daily restraint stress for a 3-h period from $8 \mathrm{~d}$ of gestation to birth had increased accumulation of lipids in the liver and increased DGAT1 gene expression (Maeyama et al., 2015). Differential methylation of $D G A T 1$ suggests an influence of prenatal stress on postnatal metabolic processes.

\section{Differential DNA Methylation in CHH Sites}

Promoter regions. There were 14 differentially methylated $\mathrm{CHH}$ sites within promoter regions in PNS compared with Control bull calves (Table 1). A greater percentage of these $\mathrm{CHH}$ sites were hypomethylated compared to hypermethylated (Table 1).

The 6 significantly $(P \leq 0.05)$ hypermethylated $\mathrm{CHH}$ sites located within promoter regions in PNS compared with Control calves are listed in Table 12. 
Table 6. Top (lowest $P$ values) 30 hypermethylated $\mathrm{CpG}$ sites located within gene body regions of genes in prenatally stressed (PNS) compared with Control calves ${ }^{1}$

\begin{tabular}{|c|c|c|c|c|c|c|c|c|}
\hline Chrom & Gene & Start & End & Strand & $\begin{array}{c}\text { Average Total CPG } \\
\text { (Control) }\end{array}$ & $\begin{array}{c}\text { Average Total } \\
\text { CPG (PNS) }\end{array}$ & $\begin{array}{l}\text { Methyl } \\
\text { Diff }\end{array}$ & $P$ value \\
\hline$\overline{\operatorname{chr} 1^{\S}}$ & $C L D N 8$ & 5036161 & 5036162 & + & 16.57 & 14.29 & 0.13 & 0.0003032 \\
\hline $\operatorname{chr} 1^{\dagger t}$ & CLSTN2 & 130108179 & 130108180 & - & 11.71 & 13.00 & 0.11 & 0.000009504 \\
\hline $\operatorname{chr} 1^{* \neq}$ & EPHB1 & 135353859 & 135353860 & - & 12.43 & 12.29 & 0.16 & 0.00003959 \\
\hline $\operatorname{chr} 2^{\dagger \neq}$ & TMEM200B & 125008770 & 125008771 & + & 12.43 & 9.71 & 0.13 & 0.00028 \\
\hline $\operatorname{chr} 3^{3^{* \S}}$ & DMRTA2 & 96456243 & 96456244 & - & 19.29 & 15.29 & 0.15 & 0.0003634 \\
\hline $\operatorname{chr} 3^{* \dagger}$ & C3H1orf52 & 59027290 & 59027291 & - & 6.29 & 8.71 & 0.15 & 0.00001461 \\
\hline $\operatorname{chr} 4^{* *}$ & $N U D C D 3$ & 77653827 & 77653828 & - & 5.86 & 6.29 & 0.4 & 0.0004187 \\
\hline $\operatorname{chr} 5^{* \dagger}$ & ZNF384 & 104130929 & 104130930 & + & 7.71 & 8.14 & 0.15 & 0.0003626 \\
\hline $\operatorname{chr} 7^{* \S}$ & F12 & 40258637 & 40258638 & - & 7.71 & 5.71 & 0.13 & 0.0004367 \\
\hline $\operatorname{chr} 7^{\dagger \S}$ & $H N R N P M$ & 18289571 & 18289572 & - & 9.43 & 8.71 & 0.21 & 0.0002804 \\
\hline $\operatorname{chr} 7^{*} \neq$ & CRTCl & 4435796 & 4435797 & + & 11.29 & 10.14 & 0.14 & 0.0004044 \\
\hline $\operatorname{chr} 11^{* \S}$ & $S L C 8 A 1$ & 22824023 & 22824024 & + & 9.57 & 8.86 & 0.29 & 0.0001272 \\
\hline $\operatorname{chr} 11^{* \ddagger}$ & EHMTI & 105461042 & 105461043 & + & 7.29 & 6.57 & 0.63 & 0.0003017 \\
\hline $\operatorname{chr} 11^{* \ddagger}$ & $R A L G D S$ & 103166859 & 103166860 & - & 7.14 & 6.29 & 0.55 & 0.00003935 \\
\hline $\operatorname{chr} 11^{* \ddagger}$ & $R A L G D S$ & 103166862 & 103166863 & - & 7.14 & 6.29 & 0.48 & 0.0001696 \\
\hline $\operatorname{chr} 11^{* \ddagger}$ & $R A L G D S$ & 103166855 & 103166856 & - & 7.14 & 6.29 & 0.55 & 0.0003 \\
\hline $\operatorname{chr} 12^{+*} \ddagger$ & $C A R S 2$ & 89257092 & 89257093 & - & 11.71 & 9.00 & 0.2 & 0.0001168 \\
\hline $\operatorname{chr} 12^{* \ddagger}$ & DOCK 9 & 79833906 & 79833907 & + & 10.00 & 6.00 & 0.2 & 0.0002803 \\
\hline $\operatorname{chr} 12^{+*}$ & GRTP1 & 90628533 & 90628534 & - & 6.57 & 6.43 & 0.11 & 0.0004244 \\
\hline $\operatorname{chr} 15^{\dagger \S}$ & CHRM4 & 77253713 & 77253714 & + & 10.71 & 6.14 & 0.13 & 0.000309 \\
\hline $\operatorname{chr} 15^{\S}$ & $M M P 7$ & 6390211 & 6390212 & + & 8.57 & 6.29 & 0.19 & 0.000205 \\
\hline $\operatorname{chr} 15^{\dagger^{* *}}$ & PHOX2A & 52625075 & 52625076 & - & 6.29 & 6.14 & 0.17 & 0.0002289 \\
\hline $\operatorname{chr19}$ & $I T G A 3$ & 37230331 & 37230332 & + & 12.29 & 11.00 & 0.12 & 0.0000896 \\
\hline $\operatorname{chr} 21^{+* \S}$ & DIO3 & 68152290 & 68152291 & + & 14.86 & 14.14 & 0.18 & 0.0001115 \\
\hline $\operatorname{chr} 22^{* \ddagger}$ & $I L 17 R D$ & 44515500 & 44515501 & - & 18.57 & 18.14 & 0.27 & 0.00007418 \\
\hline $\operatorname{chr} 23^{* \ddagger}$ & $M D G A 1$ & 11586464 & 11586465 & - & 21.14 & 15.43 & 0.17 & 0.0004023 \\
\hline $\operatorname{chr} 23^{* \dagger}$ & PHACTRI & 43380907 & 43380908 & + & 10.14 & 9.29 & 0.11 & 0.0002705 \\
\hline $\operatorname{chr} 26^{\ddagger}$ & ZWINT & 2851210 & 2851211 & + & 10.00 & 11.71 & 0.15 & 0.0001167 \\
\hline $\operatorname{chr} 28^{* \S}$ & C28H10orf35 & 26104046 & 26104047 & + & 14.00 & 8.57 & 0.15 & 0.0003049 \\
\hline chr29+*s & $N R X N 2$ & 43477994 & 43477995 & + & 10.57 & 6.71 & 0.28 & 0.0001266 \\
\hline
\end{tabular}

${ }^{1}$ In limited cases, multiple genes were represented within one recorded region. In such cases, the record was considered one site.

DNA methylation was located within a $\mathrm{CpG}$ island.

"DNA methylation was exclusively contained in the gene body region of the gene.

DNA methylation was located within an intron region.

sNA methylation was located within an exon region.

Among these was a $\mathrm{CHH}$ site within the promoter region of the Immediate Early Response 2 (IER2) gene. The IER2 gene encodes the Immediate Early Response 2 gene and is involved in neural development. Prenatal exposure to arsenic has been associated with altered IER2 gene expression, with upregulation of IER2 gene expression potentially serving as a biomarker of prenatal arsenic exposure (Fry et al., 2007).

The 8 significantly $(P \leq 0.05)$ hypomethylated $\mathrm{CHH}$ sites located within promoter regions in PNS compared with Control calves are listed in Table 13. Among these was a $\mathrm{CHH}$ site within the promoter region of the Interferon Induced Transmembrane Protein 1/Interferon Induced Transmembrane Protein 2 (IFITM1IIFITM2) genes. Patients with schizophrenia had increased IFITMI and IFITM2 gene expression, which was likely indicative of an early environmental insult (Arion et al., 2007; Hwang et al., 2013).

Gene body regions. There were 133 differentially methylated $\mathrm{CHH}$ sites within gene body regions in PNS compared with Control bull calves (Table 1). A slightly greater percentage of these $\mathrm{CHH}$ sites were hypermethylated compared to hypomethylated (Table 1).

The top (lowest $P$ values) 30 of 71 significantly $(P \leq 0.05)$ hypermethylated $\mathrm{CHH}$ sites located within gene body regions in PNS compared with Control calves are listed in Table 14. Among these was a $\mathrm{CHH}$ site within the gene body region of the 
Table 7. Top (lowest $P$ values) 30 hypomethylated $\mathrm{CpG}$ sites located within gene body regions of genes in prenatally stressed (PNS) compared with Control calves

\begin{tabular}{|c|c|c|c|c|c|c|c|c|}
\hline Chrom & Gene & Start & End & Strand & $\begin{array}{c}\text { Average Total } \\
\text { CPG (Control) }\end{array}$ & $\begin{array}{c}\text { Average Total } \\
\text { CPG (PNS) }\end{array}$ & $\begin{array}{l}\text { Methyl } \\
\text { Diff }\end{array}$ & $P$ value \\
\hline$\overline{\operatorname{chr} 2^{* \S}}$ & $C R Y B A 2$ & 107655452 & 107655453 & + & 17.86 & 12.57 & -0.28 & 0.0001131 \\
\hline $\operatorname{chr} 2^{\dagger \S}$ & TMEM $200 B$ & 125010636 & 125010637 & + & 9.00 & 7.14 & -0.12 & $6.12 \mathrm{E}-08$ \\
\hline $\operatorname{chr} 2^{* \ddagger}$ & DPP10 & 68059420 & 68059421 & + & 13.43 & 10.43 & -0.29 & 0.00007136 \\
\hline $\operatorname{chr} 3^{* \$}$ & $L R R C 42$ & 92815815 & 92815816 & - & 15.57 & 11.71 & -0.12 & 0.0003827 \\
\hline $\operatorname{chr} 3^{* \ddagger}$ & GRIK3 & 109641283 & 109641284 & - & 13.86 & 9.43 & -0.15 & 0.00006294 \\
\hline $\operatorname{chr} 5^{* \S}$ & $F M N L 3$ & 30363597 & 30363598 & + & 10.14 & 13.00 & -0.16 & 0.00001178 \\
\hline $\operatorname{chr} 6^{* *}$ & $N S G 1$ & 106743364 & 106743365 & - & 11.14 & 8.71 & -0.18 & 0.0001679 \\
\hline $\operatorname{chr} 7{ }^{\ddagger}$ & $F D X 1 L$ & 16072432 & 16072433 & + & 9.43 & 9.57 & -0.18 & 0.0004641 \\
\hline $\operatorname{chr} 9^{\S}$ & OPRMI & 92152196 & 92152197 & + & 8.14 & 9.43 & -0.13 & 0.0002767 \\
\hline $\operatorname{chr} 11^{+* *}$ & $G B G T 1$ & 103182975 & 103182976 & + & 9.43 & 9.43 & -0.6 & 0.0001948 \\
\hline $\operatorname{chr} 11^{+* *}$ & NR5Al & 95535022 & 95535023 & - & 12.57 & 11.57 & -0.12 & 0.00006977 \\
\hline $\operatorname{chr} 13^{* \star}$ & $C U B N$ & 31602752 & 31602753 & - & 24.86 & 31.14 & -0.1 & 0.0002177 \\
\hline $\operatorname{chr} 13^{* *}$ & TGIF2 & 66340155 & 66340156 & + & 8.86 & 10.14 & -0.11 & 0.0003646 \\
\hline $\operatorname{chr} 14^{+* *}$ & $A G O 2$ & 4114895 & 4114896 & - & 7.00 & 6.14 & -0.43 & 0.000509 \\
\hline $\operatorname{chr} 14^{* \ddagger}$ & $C P Q$ & 69484191 & 69484192 & + & 9.86 & 9.71 & -0.1 & 0.000005467 \\
\hline $\operatorname{chr} 15^{\dagger \S}$ & $A P L N R$ & 81738036 & 81738037 & + & 25.57 & 24.57 & -0.23 & 0.0004384 \\
\hline $\operatorname{chr} 16^{*}+$ & ACOT7 & 47839343 & 47839344 & + & 6.43 & 7.00 & -0.11 & 0.0001594 \\
\hline $\operatorname{chr} 16^{*}+$ & $R G S 7$ & 36591986 & 36591987 & - & 23.86 & 20.29 & -0.13 & 0.000143 \\
\hline $\operatorname{chr} 17^{*}$ t. & SELM & 72065070 & 72065071 & - & 16.14 & 18.14 & -0.27 & 0.0003458 \\
\hline $\operatorname{chr} 18^{*}+$ & $C B L C$ & 52956154 & 52956155 & + & 8.86 & 7.86 & -0.2 & 0.0002327 \\
\hline $\operatorname{chr19*\$ }$ & $A B R$ & 22423681 & 22423682 & - & 13.71 & 14.00 & -0.64 & 0.00003286 \\
\hline $\operatorname{chr} 19^{\ddagger}$ & $E R B B 2$ & 40722503 & 40722504 & + & 13.14 & 9.57 & -0.1 & 0.0004212 \\
\hline $\operatorname{chr} 19^{\dagger *}$ & PMP22 & 33382476 & 33382477 & - & 11.43 & 12.57 & -0.12 & 0.00007101 \\
\hline $\operatorname{chr} 22^{*}+$ & $A L D H 1 L 1$ & 61235727 & 61235728 & + & 17.00 & 12.57 & -0.15 & 0.0000172 \\
\hline $\operatorname{chr} 22^{* *}$ & $L T F$ & 53523469 & 53523470 & - & 11.14 & 8.14 & -0.24 & 0.0003724 \\
\hline $\operatorname{chr} 24^{+* *}$ & $A D C Y A P 1$ & 36118731 & 36118732 & + & 13.29 & 10.43 & -0.16 & 0.0004943 \\
\hline $\operatorname{chr} 26^{\S}$ & $P R L H R$ & 39220962 & 39220963 & + & 11.43 & 9.29 & -0.22 & 0.00008747 \\
\hline $\operatorname{chr} 26^{\ddagger}$ & $G L R X 3$ & 49743379 & 49743380 & + & 12.43 & 9.57 & -0.14 & 0.00004049 \\
\hline $\operatorname{chr} 27^{* *}$ & MTUS1 & 18657599 & 18657600 & - & 10.57 & 11.71 & -0.21 & 0.00008578 \\
\hline chr29 & MOB2 & 50986147 & 50986148 & - & 13.86 & 11.29 & -0.26 & 0.0003578 \\
\hline
\end{tabular}

${ }^{1}$ In limited cases, multiple genes were represented within one recorded region. In such cases, the record was considered one site.

DNA methylation was located within a $\mathrm{CpG}$ island.

"DNA methylation was exclusively contained in the gene body region of the gene.

DNA methylation was located within an intron region.

sDNA methylation was located within an exon region.

Table 8. Hypermethylated CHG sites located within promoter regions of genes in prenatally stressed (PNS) compared with Control calves ${ }^{1}$

\begin{tabular}{lcccccrrr}
\hline \hline Chrom & Gene & Start & End & Strand & $\begin{array}{c}\text { Average Total } \\
\text { CPG (Control) }\end{array}$ & $\begin{array}{c}\text { Average Total } \\
\text { CPG (PNS) }\end{array}$ & $\begin{array}{c}\text { Methyl } \\
\text { Diff }\end{array}$ & $\begin{array}{r}\boldsymbol{P} \text { value } \\
\text { chr1 }\end{array}$ \\
COLQ & 154285093 & 154285094 & + & 9.92 & 7.71 & 0.27 & 0.02224 \\
$\operatorname{chr} 12^{\dagger}$ & FAM155A & 87425041 & 87425042 & + & 8.00 & 5.71 & 0.16 \\
$\operatorname{chr} 17^{*}$ & CRYBB3 & 67543284 & 67543285 & + & 12.43 & 12.86 & 0.000134 \\
\hline
\end{tabular}

${ }^{1}$ In limited cases, multiple genes were represented within one recorded region. In such cases, the record was considered one site.

DNA methylation was located within a CPG island.

*DNA methylation was exclusively located within the promoter region.

Peroxisome Proliferator Activated Receptor Delta (PPARD) gene. The PPARD gene plays a key role in glucose and lipid metabolism (Brunmair et al., 2006). Male and female rats whose dams were administered dexamethasone between $13 \mathrm{~d}$ of gestation and birth exhibited hyperinsulinemia, altered glucose and fatty acid metabolism, and females (only) had increased PPARD gene expression in 
Table 9. Hypomethylated CHG sites located within promoter regions of genes in prenatally stressed (PNS) compared with Control calves ${ }^{1}$

\begin{tabular}{|c|c|c|c|c|c|c|c|c|}
\hline Chrom & Gene & Start & End & Strand & $\begin{array}{c}\text { Average Total CPG } \\
\text { (Control) }\end{array}$ & $\begin{array}{c}\text { Average Total CPG } \\
\text { (PNS) }\end{array}$ & $\begin{array}{l}\text { Methyl } \\
\text { Diff }\end{array}$ & $P$ value \\
\hline$\overline{\operatorname{chr} 4^{\dagger}}$ & $A K R 1 B 1$ & 99033535 & 99033536 & + & 5.50 & 9.00 & -0.1 & 0.00876 \\
\hline $\operatorname{chr} 7^{*}$ & $F 2 R L 3$ & 6100112 & 6100113 & - & 9.13 & 13.14 & -0.13 & 0.04596 \\
\hline $\operatorname{chr} 17$ & HIC2 & 74182640 & 74182641 & + & 7.15 & 8.00 & -0.11 & 0.01282 \\
\hline $\operatorname{chr} 18$ & $C Y P 2 S 1$ & 50656104 & 50656105 & + & 9.63 & 7.43 & -0.12 & 0.04467 \\
\hline $\operatorname{chr} 21$ & FURIN & 22213152 & 22213153 & - & 13.28 & 14.71 & -0.11 & 0.04053 \\
\hline $\operatorname{chr} 22$ & QARS & 51484825 & 51484826 & - & 9.30 & 8.86 & -0.13 & 0.01024 \\
\hline $\operatorname{chr} 25^{\dagger^{*}}$ & $S B D S$ & 28636530 & 28636531 & + & 9.39 & 10.00 & -0.11 & 0.01421 \\
\hline
\end{tabular}

${ }^{1}$ In limited cases, multiple genes were represented within one recorded region. In such cases, the record was considered one site.

DNA methylation was located within a CPG island.

"DNA methylation was exclusively located within the promoter region

Table 10. Top (lowest $P$ values) 30 hypermethylated $\mathrm{CHG}$ sites located within gene body regions of genes in prenatally stressed (PNS) compared with Control calves ${ }^{1}$

\begin{tabular}{|c|c|c|c|c|c|c|c|c|}
\hline Chrom & Gene & Start & End & Strand & $\begin{array}{l}\text { Average Total } \\
\text { CPG (Control) }\end{array}$ & $\begin{array}{l}\text { Average Total } \\
\text { CPG (PNS) }\end{array}$ & $\begin{array}{l}\text { Methyl } \\
\text { Diff }\end{array}$ & $P$ value \\
\hline$\overline{\operatorname{chr} 1^{\ddagger}}$ & $C O L Q$ & 154285093 & 154285094 & + & 11.29 & 7.71 & 0.27 & 0.02224 \\
\hline $\operatorname{chr} 2^{* \dagger}$ & $C A P Z B$ & 133916622 & 133916623 & + & 10.57 & 8.57 & 0.1 & 0.03793 \\
\hline $\operatorname{chr} 4^{* \S}$ & $A D C Y 1$ & 76872462 & 76872463 & - & 9.43 & 6.43 & 0.11 & 0.01105 \\
\hline $\operatorname{chr} 4^{*}$. & $L R G U K$ & 98721906 & 98721907 & + & 29.29 & 29.43 & 0.16 & 0.007548 \\
\hline $\operatorname{chr} 4^{*} \neq$ & $L R G U K$ & 98750277 & 98750278 & + & 11.57 & 14.57 & 0.17 & 0.03429 \\
\hline $\operatorname{chr} 4^{* \ddagger}$ & $S S P O$ & 113439057 & 113439058 & + & 8.29 & 5.00 & 0.11 & 0.04102 \\
\hline $\operatorname{chr} 5^{* \dagger}$ & CNTN1 & 40172096 & 40172097 & - & 5.43 & 5.57 & 0.11 & 0.01133 \\
\hline $\operatorname{chr} 5^{*}$ & $B T B D 11$ & 71077326 & 71077327 & + & 11.14 & 13.86 & 0.13 & 0.01252 \\
\hline $\operatorname{chr} 5^{* \neq}$ & BTBD11 & 71077307 & 71077308 & + & 12.71 & 15.29 & 0.12 & 0.01786 \\
\hline $\operatorname{chr} 5^{*} \neq$ & BTBD11 & 71077336 & 71077337 & + & 9.71 & 11.86 & 0.14 & 0.0197 \\
\hline $\operatorname{chr} 5^{*} \neq$ & $B T B D 11$ & 71077331 & 71077332 & + & 10.57 & 13.43 & 0.14 & 0.0197 \\
\hline $\operatorname{chr} 5^{*}+$ & GTSE1 & 117731307 & 117731308 & + & 14.14 & 13.71 & 0.12 & 0.02663 \\
\hline $\operatorname{chr} 10^{* \star}$ & $S L C 8 A 3$ & 82134282 & 82134283 & + & 8.14 & 6.57 & 0.11 & 0.008943 \\
\hline $\operatorname{chr} 11^{* \ddagger}$ & $A S S 1$ & 100828396 & 100828397 & - & 8.14 & 9.14 & 0.37 & 0.01106 \\
\hline $\operatorname{chr} 11^{+* \S}$ & $G B G T 1$ & 103182822 & 103182823 & + & 7.14 & 6.71 & 0.45 & 0.003044 \\
\hline $\operatorname{chr} 12^{\dagger}$ & FAM155A & 87425041 & 87425042 & + & 9.14 & 5.71 & 0.16 & 0.000134 \\
\hline $\operatorname{chr} 13^{* \dagger}$ & PLCB1 & 1664698 & 1664699 & + & 9.14 & 7.71 & 0.39 & 0.02851 \\
\hline $\operatorname{chr} 14^{* \dagger}$ & TRAPPC & 4363947 & 4363948 & + & 9.86 & 7.57 & 0.26 & 0.03318 \\
\hline $\operatorname{chr} 15^{*} \neq$ & GDPD5 & 55422374 & 55422375 & + & 9.29 & 7.00 & 0.2 & 0.002641 \\
\hline $\operatorname{chr} 16^{*}+$ & $R G S 7$ & 36590606 & 36590607 & + & 16.86 & 22.71 & 0.11 & 0.03004 \\
\hline $\operatorname{chr} 16^{* *}$ & $R G S 7$ & 36590615 & 36590616 & + & 10.43 & 11.86 & 0.1 & 0.03718 \\
\hline $\operatorname{chr} 18^{*} \S$ & $M Y A D M$ & 62023403 & 62023404 & - & 11.00 & 6.14 & 0.18 & 0.04267 \\
\hline $\operatorname{chr} 19^{* \ddagger}$ & $P R K C A$ & 63490629 & 63490630 & + & 9.57 & 10.71 & 0.1 & 0.02086 \\
\hline $\operatorname{chr} 19^{* \ddagger}$ & $T R P V 2$ & 33822975 & 33822976 & - & 8.57 & 5.86 & 0.12 & 0.01706 \\
\hline $\operatorname{chr} 22^{* \S}$ & RNF123 & 51074315 & 51074316 & - & 9.14 & 6.00 & 0.15 & 0.01264 \\
\hline $\operatorname{chr} 22^{* \S}$ & $R N F 123$ & 51074297 & 51074298 & - & 9.14 & 6.00 & 0.12 & 0.03985 \\
\hline $\operatorname{chr} 23^{*} \neq$ & $E F H C 1$ & 24617468 & 24617469 & + & 9.71 & 7.71 & 0.11 & 0.01582 \\
\hline $\operatorname{chr} 23^{*} \ddagger$ & GMDS & 51389933 & 51389934 & + & 10.14 & 12.29 & 0.14 & 0.0292 \\
\hline $\operatorname{chr} 25^{*} 8$ & INTS1 & 41995171 & 41995172 & + & 8.86 & 6.00 & 0.12 & 0.01351 \\
\hline $\operatorname{chr} 27^{+*} \dot{ }$ & CSGALNACT1 & 37970135 & 37970136 & + & 10.86 & 8.29 & 0.42 & 0.01612 \\
\hline
\end{tabular}

${ }^{1}$ In limited cases, multiple genes were represented within one recorded region. In such cases, the record was considered one site.

DNA methylation was located within a $\mathrm{CpG}$ island.

"DNA methylation was exclusively contained in the gene body region of the gene.

DNA methylation was located within an intron region.

sNA methylation was located within an exon region. 
Table 11. Top (lowest $P$ values) 30 hypomethylated $\mathrm{CHG}$ sites located within gene body regions of genes in prenatally stressed (PNS) compared with Control calves ${ }^{1}$

\begin{tabular}{|c|c|c|c|c|c|c|c|c|}
\hline Chrom & Gene & Start & End & Strand & $\begin{array}{l}\text { Average Total } \\
\text { CPG (Control) }\end{array}$ & $\begin{array}{c}\text { Average Total } \\
\text { CPG (PNS) }\end{array}$ & $\begin{array}{l}\text { Methyl } \\
\text { Diff }\end{array}$ & $P$ value \\
\hline$\overline{\operatorname{chr} 1^{*} \neq}$ & $O X N A D 1$ & 155073206 & 155073207 & - & 13.71 & 14.29 & -0.34 & 0.01431 \\
\hline $\operatorname{chr} 3^{* \ddagger}$ & TRAF3IP1 & 118294302 & 118294303 & - & 7.57 & 6.57 & -0.35 & 0.02739 \\
\hline $\operatorname{chr} 4^{\dagger \S}$ & $A K R 1 B 1$ & 99033535 & 99033536 & + & 6.29 & 9.00 & -0.1 & 0.00876 \\
\hline $\operatorname{chr} 6^{* \S}$ & PDGFRA & 71409734 & 71409735 & + & 12.57 & 8.29 & -0.1 & 0.00002454 \\
\hline $\operatorname{chr} 7^{* \ddagger}$ & $N M R K 2$ & 21292863 & 21292864 & - & 9.14 & 7.71 & -0.35 & 0.001535 \\
\hline $\operatorname{chr} 11^{* \S}$ & IFITM5 & 107203536 & 107203537 & + & 10.00 & 8.57 & -0.17 & 0.03473 \\
\hline $\operatorname{chr} 11^{* *}$ & FAM102A & 98633234 & 98633235 & + & 12.29 & 9.57 & -0.22 & 0.01901 \\
\hline $\operatorname{chr} 11^{*}$ & GTF3C5 & 103098035 & 103098036 & - & 8.43 & 7.29 & -0.11 & 0.03774 \\
\hline $\operatorname{chr} 11^{* *}$ & POMT1 & 101661140 & 101661141 & + & 8.71 & 7.71 & -0.45 & 0.005054 \\
\hline $\operatorname{chr} 13^{*}$ & CTNNBL1 & 67382273 & 67382274 & + & 11.43 & 9.14 & -0.11 & 0.01673 \\
\hline $\operatorname{chr} 14^{*} *$ & $D G A T 1$ & 1799370 & 1799371 & + & 5.86 & 6.57 & -0.11 & 0.01688 \\
\hline $\operatorname{chr} 14^{* *}$ & $D P Y S$ & 62412347 & 62412348 & + & 10.57 & 11.43 & -0.12 & 0.01354 \\
\hline $\operatorname{chr} 16^{\dagger * 8}$ & $C A M K 1 G$ & 75614071 & 75614072 & + & 7.86 & 7.43 & -0.39 & 0.006132 \\
\hline $\operatorname{chr} 17^{* \star}$ & ISCU, LOC533308 & 66689455 & 66689456 & + & 7.57 & 8.14 & -0.11 & 0.01066 \\
\hline $\operatorname{chr} 17^{\ddagger}$ & PRODH & 74182640 & 74182641 & + & 8.14 & 8.00 & -0.11 & 0.01282 \\
\hline $\operatorname{chr} 18^{* \S}$ & $G A N$ & 8018228 & 8018229 & + & 7.43 & 8.14 & -0.1 & 0.008568 \\
\hline $\operatorname{chr} 18^{+* t}$ & $D D X 19 A$ & 1774349 & 1774350 & + & 9.29 & 7.14 & -0.35 & 0.03018 \\
\hline $\operatorname{chr} 18^{* \ddagger}$ & VAT1L & 5066203 & 5066204 & - & 9.29 & 7.43 & -0.27 & 0.03996 \\
\hline $\operatorname{chr} 19^{* *}$ & $B A I A P 2$ & 52216891 & 52216892 & - & 6.14 & 6.00 & -0.1 & 0.01496 \\
\hline $\operatorname{chr} 19^{* *}$ & EXOC7 & 56206159 & 56206160 & + & 7.29 & 5.71 & -0.11 & 0.02192 \\
\hline $\operatorname{chr} 19^{*} \neq$ & $S A M D 14$ & 37166191 & 37166192 & + & 6.43 & 5.86 & -0.1 & 0.01496 \\
\hline $\operatorname{chr} 21^{\ddagger}$ & FURIN & 22213152 & 22213153 & - & 15.14 & 14.71 & -0.11 & 0.04053 \\
\hline $\operatorname{chr} 21^{*} *$ & LOC524810 & 71546924 & 71546925 & - & 33.14 & 18.57 & -0.12 & 0.02952 \\
\hline $\operatorname{chr} 21^{* *}$ & OTUD7A & 30644587 & 30644588 & + & 12.71 & 10.00 & -0.43 & 0.02269 \\
\hline $\operatorname{chr} 22^{* \ddagger}$ & $P T P R G$ & 39397678 & 39397679 & - & 10.00 & 9.00 & -0.31 & 0.0106 \\
\hline $\operatorname{chr} 22^{\ddagger}$ & $Q A R S$ & 51484825 & 51484826 & - & 10.57 & 8.86 & -0.13 & 0.01024 \\
\hline $\operatorname{chr} 27^{+^{*}}$ & $M T M R 7$ & 18983825 & 18983826 & - & 7.29 & 9.86 & -0.3 & 0.03781 \\
\hline $\operatorname{chr} 27^{* \ddagger}$ & $R N F 122$ & 28663566 & 28663567 & - & 15.86 & 18.00 & -0.24 & 0.007464 \\
\hline $\operatorname{chr} 29^{* \S}$ & TSSC4 & 49837555 & 49837556 & + & 11.14 & 10.14 & -0.15 & 0.003493 \\
\hline $\operatorname{chr} 29^{* *}$ & FAT3 & 2565099 & 2565100 & + & 16.29 & 11.86 & -0.41 & 0.01684 \\
\hline
\end{tabular}

${ }^{1}$ In limited cases, multiple genes were represented within one recorded region. In such cases, the record was considered one site.

DNA methylation was located within a $\mathrm{CpG}$ island.

*DNA methylation was exclusively contained in the gene body region of the gene.

DNA methylation was located within an intron region.

sDA methylation was located within an exon region.

Table 12. Hypermethylated $\mathrm{CHH}$ sites located within promoter regions of genes in prenatally stressed (PNS) compared with Control calves ${ }^{1}$

\begin{tabular}{|c|c|c|c|c|c|c|c|c|}
\hline Chrom & Gene & Start & End & Strand & $\begin{array}{l}\text { Average Total } \\
\text { CPG (Control) }\end{array}$ & $\begin{array}{l}\text { Average Total } \\
\text { CPG (PNS) }\end{array}$ & $\begin{array}{l}\text { Methyl } \\
\text { Diff }\end{array}$ & $P$ value \\
\hline$\overline{\operatorname{chr} 1^{*}}$ & C1H21orf91 & 18719042 & 18719043 & - & 7.00 & 7.43 & 0.13 & 0.04541 \\
\hline $\operatorname{chr}^{*}$ & ClH21orf91 & 18719029 & 18719030 & - & 7.00 & 7.43 & 0.1 & 0.01395 \\
\hline $\operatorname{chr} 4^{\dagger *}$ & $Z Y X$ & 107597956 & 107597957 & - & 5.13 & 6.57 & 0.19 & 0.01628 \\
\hline $\operatorname{chr} 5$ & LOC511240 & 72050111 & 72050112 & + & 11.00 & 9.86 & 0.22 & 0.03802 \\
\hline $\operatorname{chr} 5^{*}$ & POLR3B & 70062294 & 70062295 & - & 15.50 & 14.14 & 0.11 & 0.03267 \\
\hline $\operatorname{chr} 7^{\dagger *}$ & $I E R 2$ & 13545518 & 13545519 & - & 7.50 & 6.57 & 0.1 & 0.02712 \\
\hline
\end{tabular}

${ }^{1}$ In limited cases, multiple genes were represented within one recorded region. In such cases, the record was considered one site.

DNA methylation was located within a CPG island.

"DNA methylation was exclusively located within the promoter region. 
Table 13. Hypomethylated CHH sites located within promoter regions of genes in prenatally stressed (PNS) compared with Control calves ${ }^{1}$

\begin{tabular}{|c|c|c|c|c|c|c|c|c|}
\hline Chrom & Gene & Start & End & Strand & $\begin{array}{l}\text { Average Total } \\
\text { CPG (Control) }\end{array}$ & $\begin{array}{l}\text { Average Total } \\
\text { CPG (PNS) }\end{array}$ & $\begin{array}{l}\text { Methyl } \\
\text { Diff }\end{array}$ & $P$ value \\
\hline chr4 & $C P A 5$ & 94878884 & 94878885 & + & 8.54 & 11.29 & -0.14 & 0.03917 \\
\hline $\operatorname{chr} 5^{t^{*}}$ & $S R G A P 1$ & 50119329 & 50119330 & - & 9.28 & 11.29 & -0.12 & 0.0108 \\
\hline $\operatorname{chr} 11$ & IFITM2, IFITM1 & 107192312 & 107192313 & + & 12.05 & 10.00 & -0.22 & 0.006774 \\
\hline $\operatorname{chr} 11$ & IFITM2, IFITM1 & 107192386 & 107192387 & + & 12.93 & 11.00 & -0.19 & 0.01444 \\
\hline $\operatorname{chr} 13^{*}$ & ZSWIMI & 75359296 & 75359297 & - & 7.73 & 8.57 & -0.2 & 0.003527 \\
\hline $\operatorname{chr} 15^{*}$ & $M A M L 2$ & 14155574 & 14155575 & + & 6.77 & 7.14 & -0.15 & 0.01866 \\
\hline $\operatorname{chr} 15$ & C15H11orf74 & 67844693 & 67844694 & + & 10.75 & 13.43 & -0.1 & 0.0426 \\
\hline $\operatorname{chr} 18$ & POP4 & 40371128 & 40371129 & - & 10.53 & 14.29 & -0.11 & 0.007739 \\
\hline
\end{tabular}

\footnotetext{
${ }^{1}$ In limited cases, multiple genes were represented within one recorded region. In such cases, the record was considered one site.

DNA methylation was located within a CPG island.

*DNA methylation was exclusively located within the promoter region.
}

skeletal muscle (Wyrwoll et al., 2008). Holstein cows fed a moderate-energy (1.47 Mcal $/ \mathrm{kg})$ diet compared to Controls $(1.24 \mathrm{Mcal} / \mathrm{kg}$ ) during late gestation had lower PPARD expression compared to Controls after parturition (Osorio et al., 2013).

The top (lowest $P$ values) 30 of 62 significantly $(P \leq 0.05)$ hypomethylated $\mathrm{CHH}$ sites located within gene body regions in PNS compared with Control calves are listed in Table 15. Among these was a $\mathrm{CHH}$ site within the gene body region of the Dihydropyrimidinase-like 2 (DPYSL2) gene. The DPYSL2 gene is a collapsin response mediator protein that is involved in neurodevelopment, neurotransmission, and neurodegenerative diseases (Charrier et al., 2003). Rats whose dams underwent gestational stressors (i.e., restraint stress, food deprivation, forced swimming, reversed lightdark cycles, and overcrowding stress during dark cycles) between $14 \mathrm{~d}$ of gestation and birth exhibited decreased DPYSL2 expression and potentially increased susceptibility to schizophrenic characteristics (Lee et al., 2015). Furthermore, rats whose dams were stressed by placing them on an elevated platform made of Plexiglass twice each day for a 10-min period between 12 and $16 \mathrm{~d}$ of gestation resulted in genome-wide alterations in gene expression, including expression of DPYSL2 (Mychasiuk et al., 2011).

\section{Canonical Pathways Altered in PNS Compared with Control Bull Calves}

There were 113 canonical pathways altered ( $P$ $\leq 0.05$ ) in PNS compared with Control bull calves. Those signaling pathways and the differentially methylated genes in each pathway are represented in Supplementary Table S1. Among the pathways altered in PNS bull calves were pathways related to behavior, stress response, immune function, metabolism, and cell signaling.

Pathways related to behavior, stress response, and neural function. Many genes and multiple canonical pathways related to behavior, stress response, and neural function were significantly altered in PNS compared with Control bull calves. Several of these pathways involved the hypothalamic-pituitary-adrenal (HPA) axis, neurotransmitter signaling, and opioid signaling. The "Corticotropin Releasing Hormone Signaling" pathway was activated in PNS bull calves (Supplementary Table S1). Other studies have reported differences in methylation of genes involved in HPA axis regulation, especially at the level of the glucocorticoid receptor gene, NR3C1 (Perroud et al., 2014). Although this study did not show differences in NR3Cl methylation, it did show differences at other levels of the HPA axis, including POMC methylation. "DopamineDARPP32 Feedback in cAMP Signaling and Dopamine Receptor Signaling" pathways were activated in PNS bull calves (Supplementary Table S1). Alterations in methylation of genes and canonical pathways related to behavior, stress response, and neural function agree with increased HPA axis activity and more excitable temperaments observed in calves in the larger population from which bull calves in this study were derived (Littlejohn et al., 2016). Previous reports suggest an influence of prenatal stress on dopamine regulation, especially at the level of COMT (Thompson et al., 2012) and dopamine receptors (Berger et al., 2002). The COMT gene and 2 dopamine receptor gene subtypes (DRD1 and DRD5) were differentially methylated in PNS bull calves. The "GABA Receptor Signaling" pathway was altered 
Table 14. Top (lowest $P$ values) 30 hypermethylated $\mathrm{CHH}$ sites located within gene body regions of genes in prenatally stressed (PNS) compared with Control calves ${ }^{1}$

\begin{tabular}{|c|c|c|c|c|c|c|c|c|}
\hline Chrom & Gene & Start & End & Strand & $\begin{array}{l}\text { Average Total } \\
\text { CPG (Control) }\end{array}$ & $\begin{array}{l}\text { Average Total } \\
\text { CPG (PNS) }\end{array}$ & $\begin{array}{l}\text { Methyl } \\
\text { Diff }\end{array}$ & $P$ value \\
\hline$\overline{\operatorname{chr} 1^{* \ddagger}}$ & $C O L Q$ & 154250800 & 154250801 & - & 14.00 & 10.71 & 0.31 & 0.02325 \\
\hline $\operatorname{chr} 1^{* \ddagger}$ & SH3BP5 & 154100975 & 154100976 & - & 6.43 & 5.43 & 0.55 & 0.006741 \\
\hline $\operatorname{chr} 3^{* \ddagger}$ & $A T G 16 L 1$ & 113620590 & 113620591 & - & 12.71 & 12.00 & 0.14 & 0.001883 \\
\hline $\operatorname{chr} 5^{*} \neq$ & BTBD11 & 71077321 & 71077322 & + & 12.00 & 14.14 & 0.14 & 0.006485 \\
\hline $\operatorname{chr} 5^{* \ddagger}$ & BTBD11 & 71076725 & 71076726 & - & 26.00 & 17.14 & 0.11 & 0.009977 \\
\hline $\operatorname{chr} 5^{*} \neq$ & $B T B D 11$ & 71077305 & 71077306 & + & 12.71 & 15.29 & 0.14 & 0.01081 \\
\hline $\operatorname{chr} 5^{* \ddagger}$ & BTBD11 & 71077300 & 71077301 & + & 11.57 & 13.57 & 0.13 & 0.01306 \\
\hline $\operatorname{chr} 5^{*} \ddagger$ & $B T B D 11$ & 71077320 & 71077321 & + & 13.00 & 15.29 & 0.11 & 0.01355 \\
\hline $\operatorname{chr} 5^{* \ddagger}$ & BTBD11 & 71077302 & 71077303 & + & 12.29 & 15.00 & 0.12 & 0.01688 \\
\hline $\operatorname{chr} 5^{* \dagger}$ & BTBD11 & 71077322 & 71077323 & + & 12.00 & 14.29 & 0.13 & 0.01713 \\
\hline $\operatorname{chr} 5^{*} \ddagger$ & BTBD11 & 71077304 & 71077305 & + & 12.86 & 15.14 & 0.12 & 0.01713 \\
\hline $\operatorname{chr} 5^{*} \ddagger$ & $B T B D 11$ & 71077313 & 71077314 & + & 12.86 & 15.14 & 0.12 & 0.01786 \\
\hline chr6 $6^{*}$ & PDE5A & 7031186 & 7031187 & - & 13.57 & 9.71 & 0.25 & 0.00821 \\
\hline $\operatorname{chr} 8^{*+}$ & $M O B 3 B$ & 16811946 & 16811947 & + & 9.57 & 11.14 & 0.35 & 0.01953 \\
\hline $\operatorname{chr} 13^{* *}$ & $P K I G$ & 73718134 & 73718135 & + & 6.57 & 7.57 & 0.13 & 0.002584 \\
\hline $\operatorname{chr} 13^{*}{ }^{*}$ & $P K I G$ & 73718143 & 73718144 & + & 6.57 & 7.57 & 0.13 & 0.003265 \\
\hline $\operatorname{chr} 13^{*}+$ & $P K I G$ & 73718119 & 73718120 & + & 6.43 & 7.43 & 0.11 & 0.01428 \\
\hline $\operatorname{chr} 19^{*} \S$ & SEZ6 & 20882874 & 20882875 & + & 11.00 & 6.86 & 0.41 & 0.02207 \\
\hline $\operatorname{chr} 19^{*} *$ & $N X N$ & 22530169 & 22530170 & - & 10.29 & 9.86 & 0.39 & 0.005695 \\
\hline $\operatorname{chr} 20^{*}+$ & $D A P$ & 62637623 & 62637624 & + & 15.71 & 12.14 & 0.14 & 0.02114 \\
\hline $\operatorname{chr} 20^{*}+$ & $S K I V 2 L 2$ & 23806050 & 23806051 & - & 14.00 & 15.00 & 0.14 & 0.00286 \\
\hline $\operatorname{chr} 21^{*}+$ & FAN1 & 27938912 & 27938913 & - & 10.71 & 9.29 & 0.29 & 0.01662 \\
\hline $\operatorname{chr} 23^{*}$ & PHACTRI & 43337982 & 43337983 & - & 10.86 & 11.00 & 0.23 & 0.02088 \\
\hline $\operatorname{chr} 23^{*}+$ & PPARD & 9321494 & 9321495 & + & 7.86 & 8.57 & 0.11 & 0.01898 \\
\hline $\operatorname{chr} 23^{*}+$ & PRIM2 & 2729219 & 2729220 & - & 5.86 & 9.71 & 0.15 & 0.02263 \\
\hline $\operatorname{chr} 25^{* \S}$ & INTS1 & 41995205 & 41995206 & + & 8.86 & 6.00 & 0.12 & 0.01351 \\
\hline $\operatorname{chr} 25^{+* *}$ & $L F N G$ & 41308254 & 41308255 & - & 13.29 & 12.00 & 0.17 & 0.01471 \\
\hline $\operatorname{chr} 26^{* \ddagger}$ & $R B M 20$ & 31655067 & 31655068 & - & 11.71 & 8.43 & 0.12 & 0.008981 \\
\hline $\operatorname{chr} 27^{*}$ t & RNF122 & 28624366 & 28624367 & + & 29.00 & 14.86 & 0.11 & 0.01688 \\
\hline chr29*末 & RCOR2 & 42870766 & 42870767 & + & 11.00 & 9.57 & 0.1 & 0.01591 \\
\hline
\end{tabular}

${ }^{1}$ In limited cases, multiple genes were represented within one recorded region. In such cases, the record was considered one site.

DNA methylation was located within a CpG island.

*DNA methylation was exclusively contained in the gene body region of the gene.

DNA methylation was located within an intron region.

sDA methylation was located within an exon region.

in PNS bull calves (Supplementary Table S1). Other studies have reported differences in genes involved in GABA regulation, development of GABAergic cells, and associated anxious behavior (Berger et al., 2002; Lussier and Stevens, 2016). The "Serotonin Receptor Signaling" pathway, with an emphasis on serotonin receptor subtypes, was altered in PNS bull calves (Supplementary Table S1). Prenatal stress has been associated with differences in serotonin receptor binding, serotonin synthesis, and associated behavioral alterations (Peters, 1986; Van den Hove et al., 2006). Richetto et al. (2017) reported "Neuronal Differentiation" to be the most enriched gene ontology term associated with cell differentiation in mice that were exposed to a prenatal viral challenge on gestational day 9 or 17. Significant subterms of "Neuronal Differentiation" included: "Gamma-Aminobutyric Acidergic Differentiation, Central Nervous System Differentiation, Noradrenergic System Differentiation, and Dopamine Differentiation." Alterations to neurotransmitter pathways, such as dopamine, GABA, and serotonin have been associated with psychiatric disorders such as depression, anxiety, psychosis, and schizophrenia (Markham and Koenig, 2011). Furthermore, SNPs within the genes POMC,DRD2, DRD3, HTR2A, and $S L C 18 A 2$ have been associated with temperament in cattle (Garza-Brenner et al., 2017). These genes are part of the HPA, dopamine, and serotonin signaling pathways, each of which were predicted to be altered due to prenatal stress in this study. Previous 
Table 15. Top (lowest $P$ values) 30 hypomethylated $\mathrm{CHH}$ sites located within gene body regions of genes in prenatally stressed (PNS) compared with Control calves ${ }^{1}$

\begin{tabular}{|c|c|c|c|c|c|c|c|c|}
\hline Chrom & Gene & Start & End & Strand & $\begin{array}{l}\text { Average Total } \\
\text { CPG (Control) }\end{array}$ & $\begin{array}{c}\text { Average Total } \\
\text { CPG (PNS) }\end{array}$ & $\begin{array}{l}\text { Methyl } \\
\text { Diff }\end{array}$ & $P$ value \\
\hline$\overline{\operatorname{chr} 1^{* *}}$ & $T B C 1 D 5$ & 156103383 & 156103384 & + & 12.71 & 11.43 & -0.27 & 0.02232 \\
\hline $\operatorname{chr} 2^{* \ddagger}$ & $U B R 4$ & 134135665 & 134135666 & + & 9.29 & 7.86 & -0.37 & 0.02694 \\
\hline $\operatorname{chr} 3^{* *}$ & BARHL2 & 52695313 & 52695314 & - & 15.43 & 12.57 & -0.15 & 0.01694 \\
\hline $\operatorname{chr} 7^{* \ddagger}$ & $M A P 2 K 2$ & 21141408 & 21141409 & - & 23.00 & 16.86 & -0.29 & 0.02658 \\
\hline $\operatorname{chr} 7^{* \star}$ & PLVAP & 5687715 & 5687716 & - & 12.43 & 8.00 & -0.12 & 0.0146 \\
\hline $\operatorname{chr} 7^{* \ddagger}$ & $S L C 12 A 2$ & 27042120 & 27042121 & + & 9.00 & 10.57 & -0.11 & 0.005449 \\
\hline $\operatorname{chr} 8^{* *}$ & DPYSL2 & 75136546 & 75136547 & + & 7.14 & 8.43 & -0.32 & 0.03065 \\
\hline $\operatorname{chr} 8^{* \neq}$ & $G S N$ & 112604634 & 112604635 & + & 7.86 & 5.86 & -0.11 & 0.02649 \\
\hline $\operatorname{chr} 8^{* *}$ & TNFRSF10D & 71053599 & 71053600 & + & 72.00 & 44.71 & -0.21 & 0.03105 \\
\hline $\operatorname{chr} 10^{* *}$ & $L R R C 16 B$ & 20910389 & 20910390 & + & 14.00 & 11.71 & -0.12 & 0.01559 \\
\hline $\operatorname{chr} 11^{* \ddagger}$ & $F U B P 3$ & 100947908 & 100947909 & + & 11.43 & 13.71 & -0.56 & 0.001667 \\
\hline $\operatorname{chr} 11^{\ddagger}$ & IFITM2, IFITM1 & 107192312 & 107192313 & + & 13.71 & 10.00 & -0.22 & 0.006774 \\
\hline $\operatorname{chr} 11^{\ddagger}$ & IFITM2, IFITMI & 107192386 & 107192387 & + & 14.71 & 11.00 & -0.19 & 0.01444 \\
\hline $\operatorname{chr} 11^{* \ddagger}$ & $N A C C 2$ & 103605839 & 103605840 & - & 20.71 & 12.29 & -0.49 & 0.006619 \\
\hline $\operatorname{chr} 11^{* \ddagger}$ & NEK6 & 95337824 & 95337825 & + & 12.86 & 9.57 & -0.13 & 0.01493 \\
\hline $\operatorname{chr} 12^{* \ddagger}$ & FARPI & 79248800 & 79248801 & - & 10.29 & 11.43 & -0.28 & 0.02768 \\
\hline $\operatorname{chr} 13^{* \dagger}$ & $B C A S 1$ & 82210449 & 82210450 & + & 7.00 & 7.29 & -0.24 & 0.03362 \\
\hline $\operatorname{chr} 14^{* *}$ & $A S A P 1$ & 11452197 & 11452198 & + & 12.86 & 9.71 & -0.13 & 0.02803 \\
\hline $\operatorname{chr} 14^{* *}$ & $D P Y S$ & 62412342 & 62412343 & + & 10.43 & 11.43 & -0.12 & 0.01296 \\
\hline $\operatorname{chr} 14^{* \ddagger}$ & $D P Y S$ & 62412355 & 62412356 & + & 10.43 & 11.29 & -0.12 & 0.01296 \\
\hline $\operatorname{chr} 14^{* \ddagger}$ & $D P Y S$ & 62412345 & 62412346 & + & 10.57 & 11.43 & -0.12 & 0.01354 \\
\hline $\operatorname{chr} 15^{* *}$ & LOC509058 & 76786259 & 76786260 & - & 10.86 & 8.57 & -0.43 & 0.01323 \\
\hline $\operatorname{chr} 18^{\star \$}$ & POP4 & 40371128 & 40371129 & - & 12.00 & 14.29 & -0.11 & 0.007739 \\
\hline $\operatorname{chr} 18^{* *}$ & MTHFSD & 12404197 & 12404198 & - & 10.14 & 9.29 & -0.12 & 0.03374 \\
\hline $\operatorname{chr} 18^{* \ddagger}$ & $P E P D$ & 44033725 & 44033726 & - & 6.86 & 7.29 & -0.5 & 0.0007633 \\
\hline $\operatorname{chr} 19^{* \ddagger}$ & $R A B 37$ & 57344842 & 57344843 & - & 17.43 & 13.71 & -0.11 & 0.01538 \\
\hline $\operatorname{chr} 21^{* \dagger}$ & AKAP6 & 43500188 & 43500189 & + & 14.86 & 12.00 & -0.24 & 0.02095 \\
\hline $\operatorname{chr} 21^{* *}$ & LOC524810 & 71577837 & 71577838 & - & 19.86 & 16.29 & -0.17 & 0.02587 \\
\hline $\operatorname{chr} 21^{* *}$ & PSTPIP1 & 32652323 & 32652324 & - & 6.86 & 6.86 & -0.24 & 0.01042 \\
\hline $\operatorname{chr} 27^{* \ddagger}$ & KCNU1 & 31979794 & 31979795 & + & 8.71 & 8.57 & -0.27 & 0.03064 \\
\hline
\end{tabular}

${ }^{1}$ In limited cases, multiple genes were represented within one recorded region. In such cases, the record was considered one site.

DNA methylation was located within a $\mathrm{CpG}$ island.

*DNA methylation was exclusively contained in the gene body region of the gene.

DNA methylation was located within an intron region.

\$DNA methylation was located within an exon region.

studies are consistent with alterations in predicted pathways related to behavior, stress response, and neural function in PNS bull calves. Immune cells and brain cells may exhibit similarities in differential methylation induced by prenatal or life experiences (Provençal et al., 2012; Tylee et al., 2013; Massart et al., 2016a; Seifuddin et al., 2017). For example, rhesus monkeys that were reared by an inanimate surrogate and age-matched peers rather than their biological dam exhibited significant overlap of differential methylation of DNA in T cells and cells from the prefrontal cortex (Provençal et al., 2012). Furthermore, 9 mo after a peripheral nerve injury (i.e., a chronic pain model) was induced in young rats, $72 \%$ of the promoters that were differentially methylated in T-cells were also differentially methylated in cells from the prefrontal cortex (Massart et al., 2016a). WBC have been reported to serve as an acceptable surrogate to reflect differential methylation in brain cells; however, differential methylation in WBC may only represent a portion of differential methylation in cells from neural tissues of interest.

Pathways related to immune function. Many genes and multiple canonical pathways related to immune function were significantly altered in PNS compared with Control bull calves. This might have been expected considering DNA methylation was assessed in WBC. Several of these key pathways included, "Leukocyte Extravasation Signaling, IL-15 Production, and IL-8 Signaling, Phagosome 
Formation, and B Cell Activating Factor Signaling" (Supplementary Table S1). Alterations in methylation of immune function related genes and canonical pathways in PNS bull calves were related to differences in cytokine concentrations and leukocyte counts in response to an endotoxin challenge (Littlejohn et al., 2018). Specifically, PNS bulls had a larger increase in IFN- $\gamma$ from basal concentrations and a larger decrease in circulating monocyte counts suggesting increased extravasation of monocytes. These observations can be directly related to some of the altered pathways in this study. Alterations in immune function due to prenatal stress have been evidenced by hematology and cytokine alterations in primates, rodents, and swine (Reyes and Coe, 1997; Vanbesien-Mailliot et al., 2007; Couret et al., 2009). Richetto et al. (2017) reported the "Leukocyte Differentiation" process to be significantly altered in mice that were prenatally exposed to a viral challenge on gestational day 9 or 17. Cao-Lei et al. (2014) reported that children whose mothers were in the 1998 ice storm in Quebec during gestation had altered genome-wide DNA methylation in T cells at $13 \mathrm{yr}$ of age. Six of the top 10 functions that were reported to be altered in those PNS children were related to immune function. Specifically, each of those functions was directly involved in $\mathrm{T}$ lymphocyte function (Cao-Lei et al., 2014). Previous studies as well as methylomic and phenotypic differences related to immune function in PNS bull calves suggest a potential influence of prenatal stress on overall health and immune response in bovine.

Pathways related to metabolism. Multiple genes and canonical pathways related to metabolic function were significantly altered in PNS compared with Control bull calves. Several of these pathways included, "Leptin Signaling in Obesity, Adipogenesis pathway, and Glycine Cleavage Complex" (Supplementary Table S1). Alterations in methylation of genes and canonical pathways that were related to metabolic function were linked to differences in metabolic function observed in a subset of the larger population of bulls from which bulls in this study were derived (d'Orey Branco et al., 2016). These alterations included a differential insulin response to a glucose challenge. Specifically, PNS bulls took less time to reach peak insulin response to glucose administration, decreased time to return to baseline, and a smaller area under the insulin response curve compared to Controls. This suggested PNS bulls to have an increased sensitivity to insulin (d'Orey Branco et al., 2016). Cao-Lei et al. (2014) reported the influence of the prenatal Quebec ice storm stressor on "Type 1 Diabetes Mellitus Signaling," as predicted by differential DNA methylation of T cells at $13 \mathrm{yr}$ of age. Furthermore, male mice whose dams were exposed to repeated exposure to an aggressive lactating female during late gestation had increased circulating triglyceride concentrations, decreased hepatic 5 $\alpha$-reductase, decreased Ppar $\alpha$ mRNA expression, and decreased subcutaneous fat PEPCK mRNA expression (Brunton et al., 2013). Alterations to metabolism related pathways have implications for metabolic diseases, such as diabetes. However, alterations to metabolic processes in cattle might translate to differences in growth, gain, or feed efficiency, which could result in profitability differences in PNS cattle.

Pathways related to cell pluripotency and signaling. Many genes and canonical pathways related to cell pluripotency and cell signaling were significantly altered in PNS compared with Control bull calves.

Two pathways related to cell pluripotency that were predicted by IPA to be altered in PNS bulls were also predicted to be altered in rhesus monkeys that experienced early life maternal separation stress and a lack of maternal-rearing, including: "Human Embryonic Stem Cell Pluripotency and Role of NANOG in Mammalian Embryonic Stem Cell Pluripotency (Massart et al., 2016b)." Because DNA methylation is a primary regulator of cell-specific functions (Razin and Riggs, 1980; Suelves et al., 2016), predicted alterations to pluripotency of cells is logical and suggests developmental programming of various cell types.

Among altered cell signaling pathways was, "cAMP-mediated signaling, G-Protein Coupled Receptor Signaling, Gas Signaling, Phospholipase C Signaling, Tec Kinase Signaling, Gai Signaling, and TGF- $\beta$ Signaling" (Supplementary Table S1). Cao-Lei et al. (2014) also reported an influence of the prenatal Quebec ice storm stressor on "Phospholipase C Signaling," as predicted by differential DNA methylation of T cells at $13 \mathrm{yr}$ of age. Massart et al. (2016b) reported that rhesus monkeys undergoing early life maternal separation stress and a lack of maternal-rearing had altered genome-wide DNA methylation in CD3+ T cells from day 14 to 2 $\mathrm{y}$ of age. From that study, 5 of the top 6 canonical pathways (assessed by IPA) altered in PNS monkeys were also significantly differentially methylated in PNS bull calves in this study. Two of those mutually altered pathways were related to cell signaling: "G-protein coupled receptor signaling and cAMP-mediated cell signaling." Alterations to cell signaling pathways in previous studies and in PNS 
bull calves, suggests a potential influence of prenatal stress on many biological processes through cell signaling processes employed across many cell types.

\section{Physiological Functions Altered in PNS Compared with Control Bull Calves}

The top (most enriched) 10 "Physiological System Development and Function" terms generated by IPA software (Fig. 3) suggest a broad influence of prenatal stress on physiological systems. Six of the top 10 terms were related to developmental processes, which could occur during prenatal programming of physiological systems in utero. It is consistent with this laboratory's previous phenotypic findings (Littlejohn et al., 2016) that "Behavior" and "Nervous System Development and Function" were within the top 10 most enriched terms (Fig. 3). These data suggest a broad influence of prenatal stress on prenatal development of physiological systems.

\section{Genome-wide Overview of Differentially Methylated Regions}

Overall, genome-wide distribution of differential DNA methylation (hypermethylation and hypomethylation) in PNS compared with Control bull calves were similar to previous reports in humans and nonhuman primates (Cao-Lei et al., 2014; Massart et al., 2016b). Heat maps in Figs. 4 and 5 compare the most significant (lowest $P$ values) 100 methylation ratios (specific to each individual animal) that were hypermethylated and hypomethylated, respectively, in PNS compared with Control bull calves. Hierarchical cluster analysis was performed with regard to prenatal treatment. The dendrograms above and to the left of the heat maps represent this clustering.

Genome-wide chromosome distribution of differentially methylated $\mathrm{CpG}$ sites with regard to significance, $-\log _{10}(p$-value), is represented in the form of a Manhattan plot in Fig. 6. Fourteen $\mathrm{CpG}$ sites surpassed the $-\log _{10}(p$-value) threshold of 5. Of these sites, 1 was located exclusively within a promoter region $(E I F 3 J), 1$ was located within a promoter and gene body region (CLSTN2), 2 were located exclusively within a gene body region (TMEM200B and CPQ), and 10 were located within an intergenic region. These data reveal a diverse distribution of differentially methylated $\mathrm{CpG}$ sites in PNS calves, suggesting a substantial influence of prenatal environment on gene function. Genome-wide chromosomal distributions of DNA methylation ratios are represented in Fig. 7; these ratios were calculated from $\mathrm{CpG}$ sites within all region types with a minimum sequence read depth of 5 times $(P \leq 1.0)$. Although there was a greater percentage of significantly hypomethylated than hypermethylated $\mathrm{CpG}$ sites in PNS compared with Control bull calves (Table 1), the genome-wide illustration of all analyzed $\mathrm{CpG}$ sites in PNS and Control calves suggests the opposite relationship (Fig. 7). Overall, these data show genome-wide distribution of differential methylation across each chromosome in PNS compared with Control bull calves.

Methylation of DNA acts to control gene activity and is a primary regulator of cell-specific functions (Razin and Riggs, 1980). Methylation status of DNA can be influenced by external stimuli, resulting in altered gene expression and phenotype (Feinberg, 2010; Szyf, 2012). The epigenome is most sensitive to change during embryogenesis and perinatal development (Reik, 2007). Early life

Converted Signs CPG SITES Promoters $(P<0.05)$ - 2018-04-03 08:50 AM

Sissue Morphology
Organismal Survival
Organismal Development
Embryonic Development
Behavior
Connective Tissue Development and Function
Skeletal and Muscular System Development and Function
Tissue Development
Nervous System Development and Function
Organ Morphology

Figure 3. Top (most enriched) 10 "Physiological System Development and Function" terms associated with alterations to methylation of DNA in prenatally stressed bull calves (generated by IPA software). 


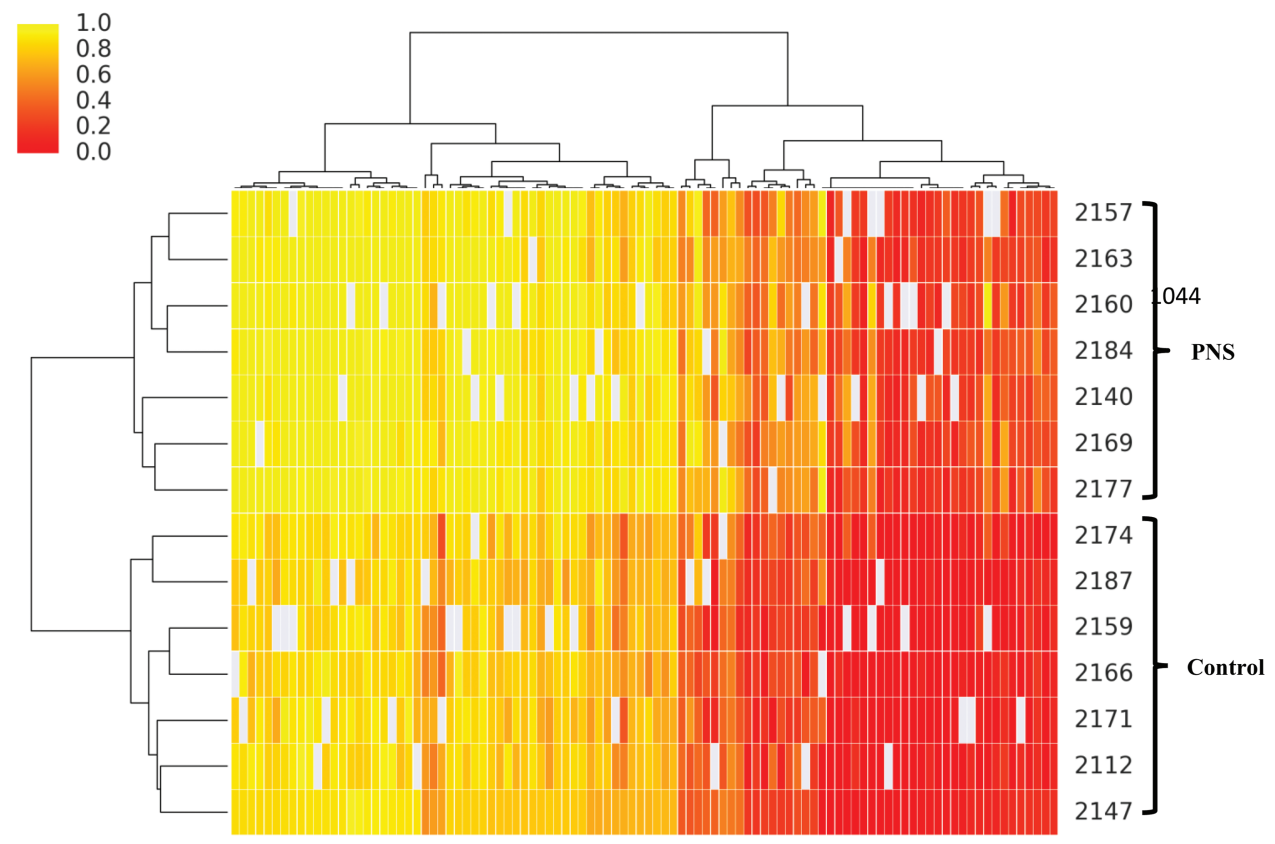

Figure 4. Comparison of the top 100 methylation ratios that were hypermethylated in prenatally stressed (PNS) compared with Control bull calves $(1.0=$ Greatest degree of methylation; $0.0=$ Least degree of methylation).

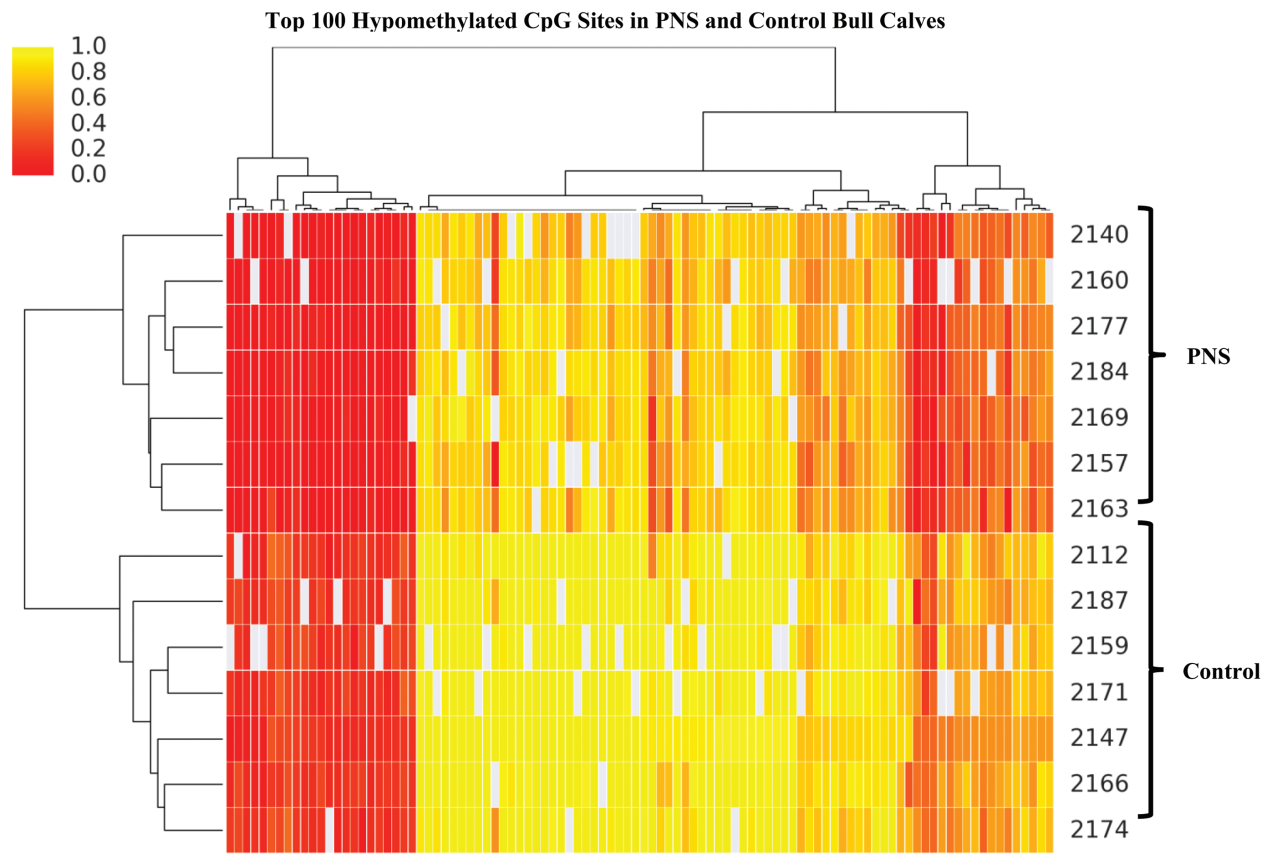

Figure 5. Comparison of the top 100 methylation ratios that were hypomethylated in prenatally stressed (PNS) compared with Control bull calves $(1.0=$ Greatest degree of methylation; $0.0=$ Least degree of methylation).

development affects many biological mechanisms, which shape phenotype in beef cattle (Alford et al., 2007; Brickell et al., 2009). Therefore, the objective of this study was evaluation of the influence of a prenatal transportation stressor on the postnatal epigenome, and how PNS-induced alterations to the epigenome might affect biological systems, and thereby economically relevant traits in cattle. In the current study, methylation was assessed in DNA of WBC from PNS and Control bull calves. Prenatal and early life stressors have been reported to alter DNA methylation in various leukocyte types (Provençal et al., 2012; Cao-Lei et al., 2014). It is important to acknowledge that differential methylation has been reported among leukocyte types (Adalsteinsson et al., 2012), which raises concern 


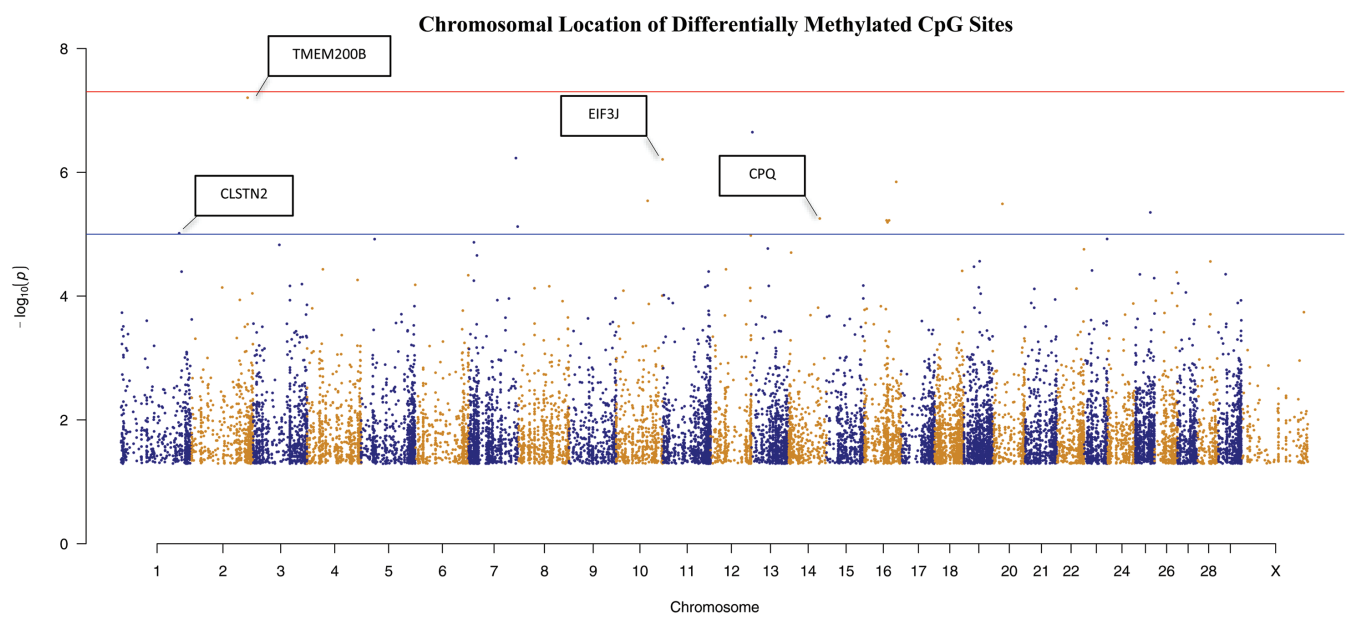

Figure 6. Manhattan plot of $-\log _{10}$ (p-values) for all differentially methylated $\mathrm{CpG}$ sites across the genome (all region types).

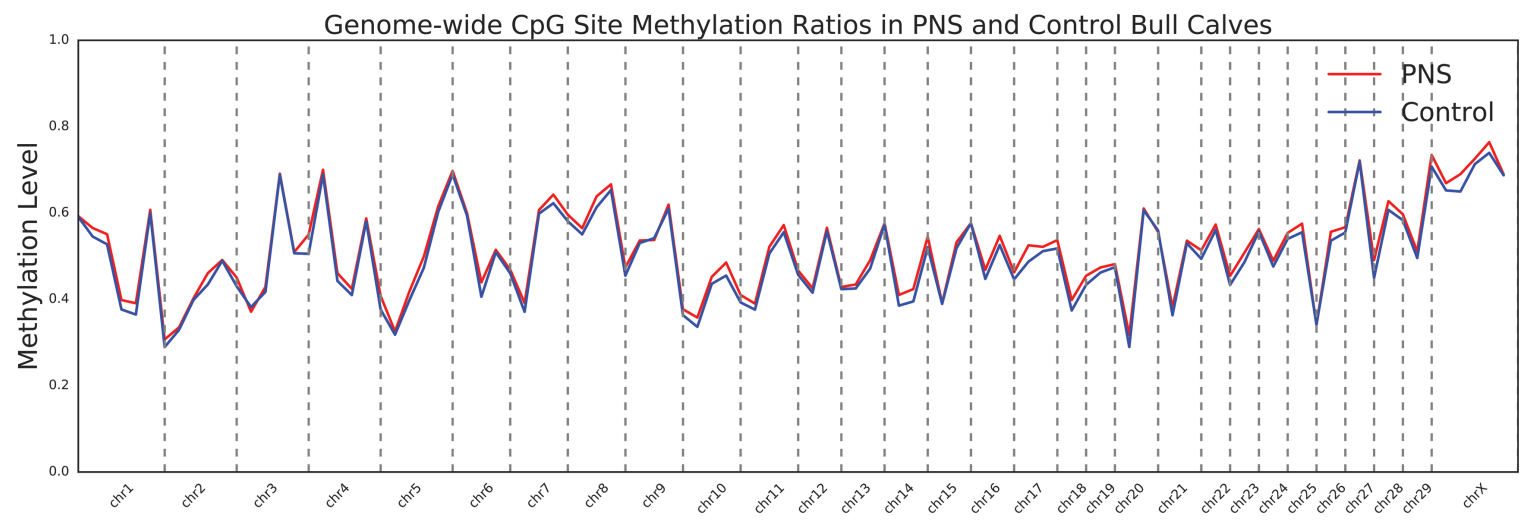

Figure 7. Comparison of genome-wide prenatally stressed (PNS; red line) and Control (blue line) CpG site methylation ratios (all region types).

with assessing a fundamentally heterogeneous population of WBC. However, Heiss and Brenner (2017) reported relatively low variation in DNA methylation among leukocyte types in humans, suggesting WBC could be an acceptable population of cells for DNA methylation analysis. Changes in methylation of DNA in WBC induced by prenatal or life experiences have been reported to be correlated with changes in methylation of DNA in various brain tissues (Provençal et al., 2012, Tylee et al., 2013; Massart et al., 2016a; Seifuddin et al., 2017); therefore, methylation of DNA from WBC can provide insight to methylation in other tissues such as neural tissue. Because differential methylation in WBC may only represent a portion of differential methylation in cells from neural tissues of interest, greater insight might be achieved by assessing tissue-specific methylation. It is also important to understand the influence of changes in DNA methylation on the transcriptome and resultant phenotype. Therefore, future studies should assess tissue-specific differences in methylation of DNA and its association with differences in transcription and phenotype due to prenatal stress.

\section{CONCLUSIONS}

To our knowledge, these data are the first reports of a genome-wide assessment of DNA methylation in PNS calves. Overall, these data exhibited similarities with data from models of prenatal stress in humans and nonhuman primates (Cao-Lei et al., 2014; Massart et al., 2016b). Prenatal transportation stress in cattle altered genome-wide DNA methylation profiles, which were predicted by IPA to alter canonical pathways related to behavior, stress response, neural function, immune function, metabolism, cell signaling, and other biological processes. Alterations in behavior, stress response, metabolism, and immune function are related with phenotypic differences observed in the population of calves from which bull calves in this study were derived (d'Orey Branco, et al., 2016; Littlejohn et al., 2016; 2018). The data presented herein demonstrate alterations of the methylome in PNS calves. Future evaluation of the inter-relationships of the methylome and transcriptome in specific tissues with phenotype of PNS calves will increase the understanding of the impact of prenatal stress on 
economically and biologically relevant phenotypic traits in a bovine model.

\section{SUPPLEMENTARY DATA}

Supplementary data are available at Journal of Animal Science online.

\section{LITERATURE CITED}

Adalsteinsson, B. T., H. Gudnason, T. Aspelund, T. B. Harris, L. J. Launer, G. Eiriksdottir, A. V. Smith, and V. Gudnason. 2012. Heterogeneity in white blood cells has potential to confound DNA methylation measurements. Plos One 7:e46705. doi:10.1371/journal. pone. 0046705

Alford, A., L. Cafe, P. Greenwood, and G. Griffith. 2007. The economic consequences of early-life nutritional constraints in crossbred cattle bred on the NSW North Coast. Economic Research Report No. 33. NSW Department of Primary Industries, Armidale, May.

Andreou, D., E. Söderman, T. Axelsson, G. C. Sedvall, L. Terenius, I. Agartz, and E. G. Jönsson. 2016. Associations between a locus downstream DRD1 gene and cerebrospinal fluid dopamine metabolite concentrations in psychosis. Neurosci. Lett. 619:126-130. doi:10.1016/j.neulet.2016.03.005

Arion, D., T. Unger, D. A. Lewis, P. Levitt, and K. Mirnics. 2007. Molecular evidence for increased expression of genes related to immune and chaperone function in the prefrontal cortex in schizophrenia. Biol. Psychiatry 62:711-721. doi:10.1016/j.biopsych.2006.12.021

Barua, S., S. Kuizon, K. K. Chadman, M. J. Flory, W. T. Brown, and M. A. Junaid. 2014. Single-base resolution of mouse offspring brain methylome reveals epigenome modifications caused by gestational folic acid. Epigenetics Chromatin 7:3. doi:10.1186/1756-8935-7-3

Benediktsson, R., A. A. Calder, C. R. Edwards, and J. R. Seckl. 1997. Placental 11 beta-hydroxysteroid dehydrogenase: a key regulator of fetal glucocorticoid exposure. Clin. Endocrinol. (Oxf). 46:161-166. doi:10.1046/j.1365-2265.1997.1230939.x

Berger, M. A., V. G. Barros, M. I. Sarchi, F. I. Tarazi, and M. C. Antonelli. 2002. Long-term effects of prenatal stress on dopamine and glutamate receptors in adult rat brain. Neurochem. Res. 27:1525-1533. doi:10.102 3/A:1021656607278

Bernal, J. 2005. Thyroid hormones and brain development. Vitam. Horm. 71:95-122. doi:10.1016/ S0083-6729(05)71004-9

Breitling, L. P., K. Salzmann, D. Rothenbacher, B. Burwinkel, and H. Brenner. 2012. Smoking, F2RL3 methylation, and prognosis in stable coronary heart disease. Eur. Heart J. 33:2841-2848. doi:10.1093/eurheartj/ehs091

Brickell, J. S., M. M. McGowan, and D. C. Wathes. 2009. Effect of management factors and blood metabolites during the rearing period on growth in dairy heifers on UK farms. Domest. Anim. Endocrinol. 36:67-81. doi:10.1016/j. domaniend.2008.10.005.

Brunmair, B., K. Staniek, J. Dörig, Z. Szöcs, K. Stadlbauer, V. Marian, F. Gras, C. Anderwald, H. Nohl, W. Waldhäusl, et al. 2006. Activation of PPAR-delta in isolated rat skeletal muscle switches fuel preference from glucose to fatty acids. Diabetologia 49:2713-2722. doi:10.1007/ s00125-006-0357-6

Brunton, P. J., K. M. Sullivan, D. Kerrigan, J. A. Russell, J. R. Seckl, and A. J. Drake. 2013. Sex-specific effects of prenatal stress on glucose homoeostasis and peripheral metabolism in rats. J. Endocrinol. 217:161-173. doi:10.1530/ JOE-12-0540

Cao-Lei, L., R. Massart, M. J. Suderman, Z. Machnes, G. Elgbeili, D. P. Laplante, M. Szyf, and S. King. 2014. DNA methylation signatures triggered by prenatal maternal stress exposure to a natural disaster: project ice storm. Plos One 9:e107653. doi:10.1371/journal.pone.0107653

Charrier, E., S. Reibel, V. Rogemond, M. Aguera, N. Thomasset, and J. Honnorat. 2003. Collapsin response mediator proteins (CRMPs): involvement in nervous system development and adult neurodegenerative disorders. Mol. Neurobiol. 28:51-64. doi:10.1385/MN:28:1:51

Chocyk, A., A. Przyborowska, D. Dudys, I. Majcher, M. Maćkowiak, and K. Wędzony. 2011. The impact of maternal separation on the number of tyrosine hydroxylase-expressing midbrain neurons during different stages of ontogenesis. Neuroscience 182:43-61. doi:10.1016/j. neuroscience.2011.03.008

Clarke, A. S., A. Soto, T. Bergholz, and M. L. Schneider. 1996. Maternal gestational stress alters adaptive and social behavior in adolescent Rhesus monkey offspring. Infant Behav. Dev. 19:451-461. doi:10.1016/ S0163-6383(96)90006-5

Couret, D., A. Prunier, A. M. Mounier, F. Thomas, I. P. Oswald, and E. Merlot. 2009. Comparative effects of a prenatal stress occurring during early or late gestation on pig immune response. Physiol. Behav. 98:498-504. doi:10.1016/j.physbeh.2009.08.003

d'Orey Branco, R. A., D. A. Neuendorff, S. E. Schmidt, N. C. Burdick Sanchez, J. A. Carroll, T. H. Welsh, R. D. Randel. 2016. Influence of prenatal stress on insulin response to a glucose challenge in yearling Brahman bulls. J. Anim. Sci. 94(Suppl 1):33. (Abstr. 066). doi:10.2527/ssasas2015-066

Ehrlich, M., M. A. Gama-Sosa, L. H. Huang, R. M. Midgett, K. C. Kuo, R. A. McCune, and C. Gehrke. 1982. Amount and distribution of 5-methylcytosine in human DNA from different types of tissues or cells. Nucleic Acids Res. 10:2709-2721. doi:10.1093/nar/10.8.2709

FASS. 2010. Guide for the care and use of agricultural animals in research and teaching. 3rd ed. FASS, Champaign, IL.

Feinberg, A. P. 2010. Genome-scale approaches to the epigenetics of common human disease. Virchows Arch. 456:1321. doi:10.1007/s00428-009-0847-2

Fry, R. C., P. Navasumrit, C. Valiathan, J. P. Svensson, B. J. Hogan, M. Luo, S. Bhattacharya, K. Kandjanapa, S. Soontararuks, S. Nookabkaew, et al. 2007. Activation of inflammation/NF-kappaB signaling in infants born to arsenic-exposed mothers. Plos Genet. 3:e207. doi:10.1371/ journal.pgen.0030207

Garbett, K. A., E. Y. Hsiao, S. Kálmán, P. H. Patterson, and K. Mirnics. 2012. Effects of maternal immune activation on gene expression patterns in the fetal brain. Transl. Psychiatry 2:e98. doi:10.1038/tp.2012.24

Garza-Brenner, E., A. M. Sifuentes-Rincón, R. D. Randel, F. A. Paredes-Sánchez, G. M. Parra-Bracamonte, W. Arellano Vera, F. A. Rodríguez Almeida, and A. Segura Cabrera. 2017. Association of SNPs in dopamine and serotonin pathway genes and their interacting genes with 
temperament traits in Charolais cows. J. Appl. Genet. 58:363-371. doi:10.1007/s13353-016-0383-0

Harada, S., H. Tachikawa, and Y. Kawanishi. 2003. A possible association between an insertion/deletion polymorphism of the NQO2 gene and schizophrenia. Psychiatr. Genet. 13:205-209. doi:10.1097/01.ypg.0000071601.59979.47

Heiss, J. A., and H. Brenner. 2017. Impact of confounding by leukocyte composition on associations of leukocyte DNA methylation with common risk factors. Epigenomics 9:659-668. doi:10.2217/epi-2016-0154

Hellman, A., and A. Chess. 2007. Gene body-specific methylation on the active X chromosome. Science 315:1141-1143. doi:10.1126/science.1136352

Hwang, Y., J. Kim, J. Y. Shin, J. I. Kim, J. S. Seo, M. J. Webster, D. Lee, and S. Kim. 2013. Gene expression profiling by mRNA sequencing reveals increased expression of immune/inflammation-related genes in the hippocampus of individuals with schizophrenia. Transl. Psychiatry 3:e321. doi:10.1038/tp.2013.94

Ishihama, T., Y. Ago, N. Shintani, H. Hashimoto, A. Baba, K. Takuma, and T. Matsuda. 2010. Environmental factors during early developmental period influence psychobehavioral abnormalities in adult PACAP-deficient mice. Behav. Brain Res. 209:274-280. doi:10.1016/j.bbr.2010.02.009

Lay, D. C., Jr, R. D. Randel, T. H. Friend, O. C. Jenkins, D. A. Neuendorff, D. M. Bushong, E. K. Lanier, and M. K. Bjorge. 1997. Effects of prenatal stress on suckling calves. J. Anim. Sci. 75:3143-3151. doi:10.2527/1997.75123143x

Lee, S., T. Devamani, H. D. Song, M. Sandhu, A. Larsen, R. Sommese, A. Jain, N. Vaidehi, and S. Sivaramakrishnan. 2017. Distinct structural mechanisms determine substrate affinity and kinase activity of protein kinase C. J. Biol. Chem. 292:16300-16309. doi:10.1074/jbc.M117.804781

Lee, H., J. Joo, S. S. Nah, J. W. Kim, H. K. Kim, J. T. Kwon, H. Y. Lee, Y. O. Kim, and H. J. Kim. 2015. Changes in dpys12 expression are associated with prenatally stressed rat offspring and susceptibility to schizophrenia in humans. Int. J. Mol. Med. 35:1574-1586. doi:10.3892/ijmm.2015.2161

Levine, A., G. L. Cantoni, and A. Razin. 1991. Inhibition of promoter activity by methylation: possible involvement of protein mediators. Proc. Natl. Acad. Sci. USA. 88:65156518. doi: $10.1073 /$ pnas.88.15.6515

Lister, R., M. Pelizzola, R. H. Dowen, R. D. Hawkins, G. Hon, J. Tonti-Filippini, J. R. Nery, L. Lee, Z. Ye, Q. M. Ngo, et al. 2009. Human DNA methylomes at base resolution show widespread epigenomic differences. Nature 462:315322. doi:10.1038/nature08514

Littlejohn, B. P., D. M. Price, J. P. Banta, A. W. Lewis, D. A. Neuendorff, J. A. Carroll, R. C. Vann, T. H. Welsh, and R. D. Randel. 2016. Prenatal transportation stress alters temperament and serum cortisol concentrations in suckling Brahman calves. J. Anim. Sci. 94:602-609. doi:10.2527/ jas.2015-9635

Littlejohn, B. P., N. C. Burdick Sanchez, J. A. Carroll, D. M. Price, R. C. Vann, T. H. Welsh, Jr., and R. D. Randel. 2018. Influence of prenatal transportation stress on innate immune response to an endotoxin challenge in weaned Brahman bull calves. Stress doi:10.1080/10253890.2018. 1523895

Lussier, S. J., and H. E. Stevens. 2016. Delays in GABAergic interneuron development and behavioral inhibition after prenatal stress. Dev. Neurobiol. 76:1078-1091. doi:10.1002/dneu.22376
Maeyama, H., T. Hirasawa, Y. Tahara, C. Obata, H. Kasai, K. Moriishi, K. Mochizuki, and T. Kubota. 2015. Maternal restraint stress during pregnancy in mice induces $11 \beta$-HSD1-associated metabolic changes in the livers of the offspring. J. Dev. Orig. Health Dis. 6:105-114. doi:10.1017/S2040174415000100

Markham, J. A., and J. I. Koenig. 2011. Prenatal stress: role in psychotic and depressive diseases. Psychopharmacology (Berl). 214:89-106. doi:10.1007/s00213-010-2035-0

Masilamoni, J. G., E. P. Jesudason, B. Baben, C. E. Jebaraj, S. Dhandayuthapani, and R. Jayakumar. 2006. Molecular chaperone alpha-crystallin prevents detrimental effects of neuroinflammation. Biochim. Biophys. Acta 1762:284 293. doi:10.1016/j.bbadis.2005.11.007

Massart, R., S. Dymov, M. Millecamps, M. Suderman, S. Gregoire, K. Koenigs, S. Alvarado, M. Tajerian, L. S. Stone, and M. Szyf. 2016a. Overlapping signatures of chronic pain in the DNA methylation landscape of prefrontal cortex and peripheral T cells. Sci. Rep. 6:19615. doi:10.1038/srep19615

Massart, R., Z. Nemoda, M. J. Suderman, S. Sutti, A. M. Ruggiero, A. M. Dettmer, S. J. Suomi, and M. Szyf. 2016b. Early life adversity alters normal sex-dependent developmental dynamics of DNA methylation. Dev. Psychopathol. 28(4pt2):1259-1272. doi:10.1017/S0954579416000833

Middleton, F. A., K. Mirnics, J. N. Pierri, D. A. Lewis, and P. Levitt. 2002. Gene expression profiling reveals alterations of specific metabolic pathways in schizophrenia. J. Neurosci. 22:2718-2729. doi:20026209

Mohammed, S. A., S. A. Rahamtalla, S. S. Ahmed, A. Elhafiz, B. M. Dousa, K. M. Elamin, and M. K. A. Ahmed. 2015. DGAT1 gene in dairy cattle. GJASR. 3:191-198.

Mueller, B. R., and T. L. Bale. 2008. Sex-specific programming of offspring emotionality after stress early in pregnancy. J. Neurosci. 28:9055-9065. doi:10.1523/ JNEUROSCI.1424-08.2008

Mychasiuk, R., R. Gibb, and B. Kolb. 2011. Prenatal stress produces sexually dimorphic and regionally specific changes in gene expression in hippocampus and frontal cortex of developing rat offspring. Dev. Neurosci. 33:531-538. doi:10.1159/000335524

Osorio, J. S., E. Trevisi, M. A. Ballou, G. Bertoni, J. K. Drackley, and J. J. Loor. 2013. Effect of the level of maternal energy intake prepartum on immunometabolic markers, polymorphonuclear leukocyte function, and neutrophil gene network expression in neonatal Holstein heifer calves. J. Dairy Sci. 96:3573-3587. doi:10.3168/jds.2012-5759

Ousman, S. S., B. H. Tomooka, J. M. van Noort, E. F. Wawrousek, K. C. O'Connor, D. A. Hafler, R. A. Sobel, W. H. Robinson, and L. Steinman. 2007. Protective and therapeutic role for alphab-crystallin in autoimmune demyelination. Nature 448:474 479. doi:10.1038/nature05935

Perroud, N., E. Rutembesa, A. Paoloni-Giacobino, J. Mutabaruka, L. Mutesa, L. Stenz, A. Malafosse, and F. Karege. 2014. The tutsi genocide and transgenerational transmission of maternal stress: epigenetics and biology of the HPA axis. World J. Biol. Psychiatry 15:334-345. doi:10.3109/15622975.2013.866693

Peters, D. A. 1986. Prenatal stress: effect on development of rat brain serotonergic neurons. Pharmacol. Biochem. Behav. 24:1377-1382. doi:10.1016/0091-3057(86)90198-X

Plagge, A., E. Gordon, W. Dean, R. Boiani, S. Cinti, J. Peters, and G. Kelsey. 2004. The imprinted signaling protein XL 
alpha $\mathrm{s}$ is required for postnatal adaptation to feeding. Nat. Genet. 36:818-826. doi:10.1038/ng1397

Price, D. M., A. W. Lewis, D. A. Neuendorff, J. A. Carroll, N. C. Burdick Sanchez, R. C. Vann, T. H. Welsh, and R. D. Randel. 2015. Physiological and metabolic responses of gestating Brahman cows to repeated transportation. J. Anim. Sci. 93:737-745. doi:10.2527/jas.2013-7508

Provençal, N., M. J. Suderman, C. Guillemin, R. Massart, A. Ruggiero, D. Wang, A. J. Bennett, P. J. Pierre, D. P. Friedman, S. M. Côté, et al. 2012. The signature of maternal rearing in the methylome in rhesus macaque prefrontal cortex and T cells. J. Neurosci. 32:15626-15642. doi:10.1523/JNEUROSCI.1470-12.2012

de Quervain, D. J., I. T. Kolassa, S. Ackermann, A. Aerni, P. Boesiger, P. Demougin, T. Elbert, V. Ertl, L. Gschwind, N. Hadziselimovic, et al. 2012. Pkc $\alpha$ is genetically linked to memory capacity in healthy subjects and to risk for posttraumatic stress disorder in genocide survivors. Proc. Natl. Acad. Sci. USA. 109:8746-8751. doi:10.1073/ pnas. 1200857109

Ramsahoye, B. H., D. Biniszkiewicz, F. Lyko, V. Clark, A. P. Bird, and R. Jaenisch. 2000. Non-CpG methylation is prevalent in embryonic stem cells and may be mediated by DNA methyltransferase 3a. Proc. Natl. Acad. Sci. USA. 97:5237-5242. doi:10.1073/pnas.97.10.5237

Razin, A., and A. D. Riggs. 1980. DNA methylation and gene function. Science 210:604-610. doi:10.1126/ science. 6254144

Reik, W. 2007. Stability and flexibility of epigenetic gene regulation in mammalian development. Nature 447:425-432. doi:10.1038/nature05918

Ressler, K. J., K. B. Mercer, B. Bradley, T. Jovanovic, A. Mahan, K. Kerley, S. D. Norrholm, V. Kilaru, A. K. Smith, A. J. Myers, et al. 2011. Post-traumatic stress disorder is associated with PACAP and the PAC1 receptor. Nature 470:492-497. doi:10.1038/nature09856

Reyes, T. M., and C. L. Coe. 1997. Prenatal manipulations reduce the proinflammatory response to a cytokine challenge in juvenile monkeys. Brain Res. 769:29-35. doi:10.1016/S0006-8993(97)00687-2

Richetto, J., R. Massart, U. Weber-Stadlbauer, M. Szyf, M. A. Riva, and U. Meyer. 2017. Genome-wide DNA methylation changes in a mouse model of infection-mediated neurodevelopmental disorders. Biol. Psychiatry 81:265-276. doi:10.1016/j.biopsych.2016.08.010

Rodgers, A. B., and T. L. Bale. 2015. Germ cell origins of posttraumatic stress disorder risk: the transgenerational impact of parental stress experience. Biol. Psychiatry 78:307-314. doi:10.1016/j.biopsych.2015.03.018

Rodgers, A. B., C. P. Morgan, S. L. Bronson, S. Revello, and T. L. Bale. 2013. Paternal stress exposure alters sperm microRNA content and reprograms offspring HPA stress axis regulation. J. Neurosci. 33:9003-9012. doi:10.1523/ JNEUROSCI.0914-13.2013

Seifuddin, F., G. Wand, O. Cox, M. Pirooznia, L. Moody, X. Yang, J. Tai, G. Boersma, K. Tamashiro, P. Zandi, et al. 2017. Genome-wide methyl-seq analysis of blood-brain targets of glucocorticoid exposure. Epigenetics 12:637652. doi:10.1080/15592294.2017.1334025

Shinohara, H., Y. Inaguma, S. Goto, T. Inagaki, and K. Kato. 1993. Alpha Bcrystallin and HSP28 are enhanced in thecerebral cortex of patients with Alzheimer's disease. J. Neurol. Sci. 119:203-208. doi:10.1016/0022-510X(93)90135-L
Shirane, K., H. Toh, H. Kobayashi, F. Miura, H. Chiba, T. Ito, T. Kono, and H. Sasaki. 2013. Mouse oocyte methylomes at base resolution reveal genome-wide accumulation of nonCpG methylation and role of DNA methyltransferases. Plos Genet. 9:e1003439. doi:10.1371/journal.pgen.1003439

Shukla, P. K., L. J. Sittig, T. M. Ullmann, and E. E. Redei. 2011. Candidate placental biomarkers for intrauterine alcohol exposure. Alcohol. Clin. Exp. Res. 35:559-565. doi:10.1111/j.1530-0277.2010.01373.x

Sikora, K. M., D. A. Magee, E. W. Berkowicz, D. P. Berry, D. J. Howard, M. P. Mullen, R. D. Evans, D. E. Machugh, and C. Spillane. 2011. DNA sequence polymorphisms within the bovine guanine nucleotide-binding protein Gs subunit alpha (Gs $\alpha$ )-encoding (GNAS) genomic imprinting domain are associated with performance traits. BMC Genet. 7:12-4. doi:10.1186/1471-2156-12-4

Silva, C. F., E. S. Sartorelli, A. C. Castilho, R. A. Satrapa, R. Z. Puelker, E. M. Razza, J. S. Ticianelli, H. P. Eduardo, B. Loureiro, and C. M. Barros. 2013. Effects of heat stress on development, quality and survival of bos indicus and bos taurus embryos produced in vitro. Theriogenology 79:351-357. doi:10.1016/j.theriogenology.2012.10.003

Stirrat, L. I., B. G. Sengers, J. E. Norman, N. Z. M. Homer, R. Andrew, R. M. Lewis, and R. M. Reynolds. 2018. Transfer and metabolism of cortisol by the isolated perfused human placenta. J. Clin. Endocrinol. Metab. 103:640-648. doi:10.1210/jc.2017-02140

Stohn, J. P., M. E. Martinez, M. Zafer, D. López-Espíndola, L. M. Keyes, and A. Hernandez. 2018. Increased aggression and lack of maternal behavior in dio3-deficient mice are associated with abnormalities in oxytocin and vasopressin systems. Genes. Brain. Behav. 17:23-35. doi:10.1111/gbb.12400

Suelves, M., E. Carrió, Y. Núñez-Álvarez, and M. A. Peinado. 2016. DNA methylation dynamics in cellular commitment and differentiation. Brief. Funct. Genomics 15:443-453. doi:10.1093/bfgp/elw017

Szyf, M. 2012. The early-life social environment and DNA methylation. Clin. Genet. 81:341-349. doi:10.1111/j.1399-0004.2012.01843.x

Tate, P. H., and A. P. Bird. 1993. Effects of DNA methylation on DNA-binding proteins and gene expression. Curr. Opin. Genet. Dev. 3:226-231. doi:10.1016/0959-437X(93)90027-M

Thompson, J. M., E. J. Sonuga-Barke, A. R. Morgan, C. M. Cornforth, D. Turic, L. R. Ferguson, E. A. Mitchell, and K. E. Waldie. 2012. The catechol-O-methyltransferase (COMT) Val158Met polymorphism moderates the effect of antenatal stress on childhood behavioural problems: longitudinal evidence across multiple ages. Dev. Med. Child Neurol. 54:148-154. doi:10.1111/j.1469-8749.2011.04129.X

Tsai, C. E., S. P. Lin, M. Ito, N. Takagi, S. Takada, and A. C. Ferguson-Smith. 2002. Genomic imprinting contributes to thyroid hormone metabolism in the mouse embryo. Curr. Biol. 12:1221-1226. doi:10.1016/ S0960-9822(02)00951-X

Tylee, D. S., D. M. Kawaguchi, and S. J. Glatt. 2013. On the outside, looking in: a review and evaluation of the comparability of blood and brain "-omes". Am. J. Med. Genet. B. Neuropsychiatr. Genet. 162B:595-603. doi:10.1002/ ajmg.b. 32150

Van den Hove, D. L. A., J. M. Lauderc, A. Scheepensd, J. Prickaertsb, C. E. Blancoa, and H. W. M. Steinbuschb. 
2006. Prenatal stress in the rat alters 5-HT1A receptor binding in the ventral hippocampus. Brain Res. 1090:29 34. doi:10.1016/j.brainres.2006.03.057

Vanbesien-Mailliot, C. C., I. Wolowczuk, J. Mairesse, O. Viltart, M. Delacre, J. Khalife, M. C. Chartier-Harlin, and S. Maccari. 2007. Prenatal stress has pro-inflammatory consequences on the immune system in adult rats. Psychoneuroendocrinology 32:114-124. doi:10.1016/j. psyneuen.2006.11.005

Vangeel, E. B., B. Izzi, T. Hompes, K. Vansteelandt, D. Lambrechts, K. Freson, and S. Claes. 2015. DNA methylation in imprinted genes IGF2 and GNASXL is associated with prenatal maternal stress. Genes. Brain. Behav. 14:573-582. doi:10.1111/gbb.12249

Varley, K. E., J. Gertz, K. M. Bowling, S. L. Parker, T. E. Reddy, F. Pauli-Behn, M. K. Cross, B. A. Williams, J. A. Stamatoyannopoulos, G. E. Crawford, et al. 2013. Dynamic DNA methylation across diverse human cell lines and tissues. Genome Res. 23:555-567. doi:10.1101/gr.147942.112

Wyatt, G. R. 1950. Occurrence of 5-methylcytosine in nucleic acids. Nature 166:237-238. doi:10.1038/166237b0

Wyrwoll, C. S., P. J. Mark, T. A. Mori, and B. J. Waddell. 2008. Developmental programming of adult hyperinsulinemia, increased proinflammatory cytokine production, and altered skeletal muscle expression of SLC2A4 (GLUT4) and uncoupling protein 3. J. Endocrinol. 198:571-579. doi:10.1677/JOE-08-0210

Xie, Y., A. Awonuga, J. Liu, E. Rings, E. E. Puscheck, and D. A. Rappolee. 2013. Stress induces AMPK-dependent loss of potency factors id2 and cdx2 in early embryos and stem cells [corrected]. Stem Cells Dev. 22:1564-1575. doi:10.1089/scd.2012.0352
Yang, W., D. Li, G. Wang, X. Wu, M. Zhang, C. Zhang, Y. Cui, and S. Li. 2017. Expression and imprinting of DIO3 and DIO3OS genes in Holstein cattle. J. Genet. 96:333-339. doi:10.1007/s12041-017-0780-0

Yen, C. L., S. J. Stone, S. Koliwad, C. Harris, and R. V. Farese, Jr. 2008. DGAT enzymes and triacylglycerol biosynthesis. J. Lipid Res. 49:2283-2301. doi:10.1194/jlr. R800018-JLR200

Zhang, X. G., H. Zhang, X. L. Liang, Q. Liu, H. Y. Wang, B. Cao, J. Cao, S. Liu, Y. J. Long, W.Y. Xie, and D. Z. Peng. 2016. Epigenetic mechanism of maternal post-traumatic stress disorder in delayed rat offspring development: dysregulation of methylation and gene expression. Genet. Mol. Res. 15:gmr9009. doi:10.4238/ gmr.15039009

Zhou, Y., L. Xu, D. M. Bickhart, E. H. abdel Hay, S. G. Schroeder, E. E. Connor, L. J. Alexander, T. S. Sonstegard, C. P. Van Tassell, H. Chen, et al. 2016. Reduced representation bisulphite sequencing of ten bovine somatic tissues reveals DNA methylation patterns and their impacts on gene expression. BMC Genomics. 17:779. doi:10.1186/s12864-016-3116-1

Zhu, X., T. Li, S. Peng, X. Ma, X. Chen, and X. Zhang. 2010. Maternal deprivation-caused behavioral abnormalities in adult rats relate to a non-methylation-regulated D2 receptor levels in the nucleus accumbens. Behav. Brain Res. 209:281-288. doi:10.1016/j.bbr.2010.02.005

Ziller, M. J., F. Müller, J. Liao, Y. Zhang, H. Gu, C. Bock, P. Boyle, C. B. Epstein, B. E. Bernstein, T. Lengauer, et al. 2011. Genomic distribution and inter-sample variation of non-CpG methylation across human cell types. Plos Genet. 7:e1002389. doi:10.1371/journal.pgen.1002389 